\title{
التفريق حسب عناصر تثخيص الضريبة دراسة قانونية تحليلية مقارنة
}

Doi: $10.23918 /$ ilic2020.15

م. د.شيث مصطفى خضر كاكه شين الأرين

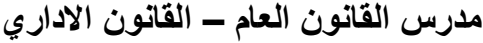

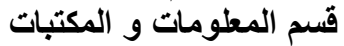

المعهل التقني الاداري في أربيل

جامعة اربيل التقية الإية

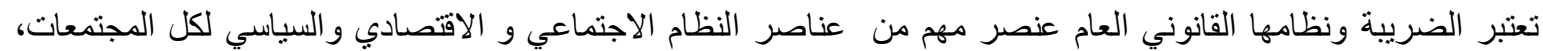

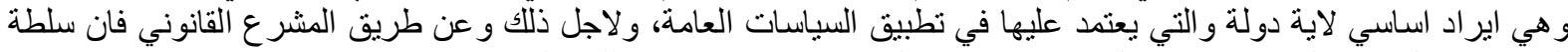

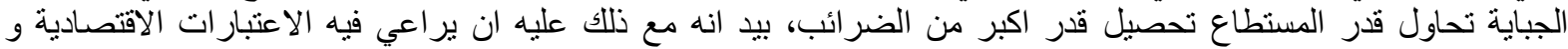

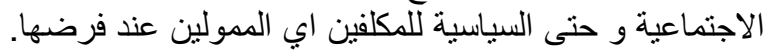

ويتم تحديد الدخل الخاضع لتحصيل الضريبة بموجب هذا التابين التشريع الضريبي، اي الدخل الصافي للمكلف وذللك بعد تنزيل كل

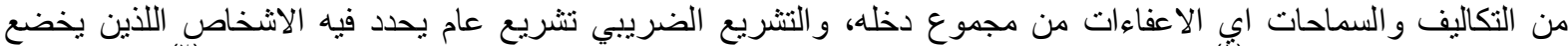

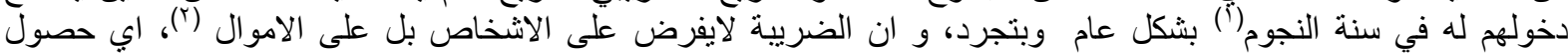

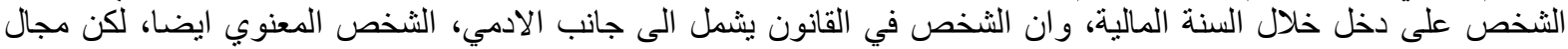
بحثنا هو الثخص الادمي.

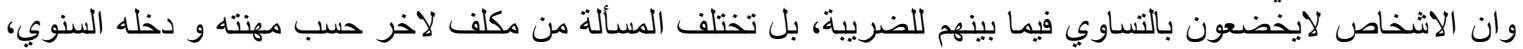

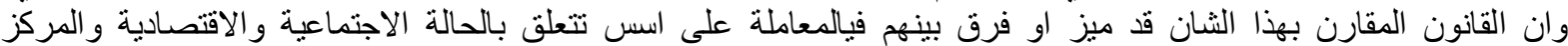

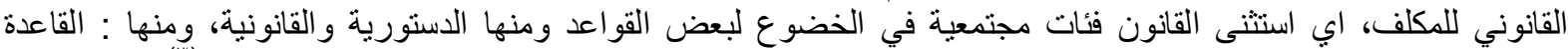

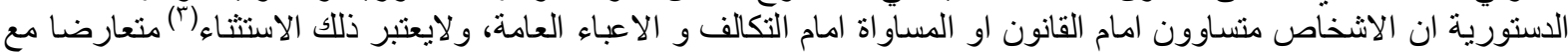

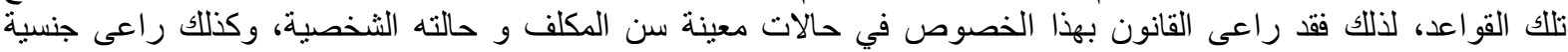

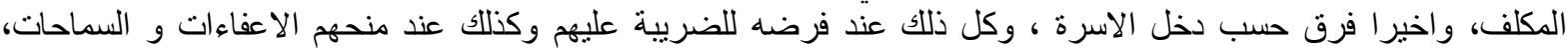

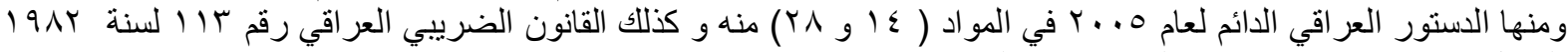

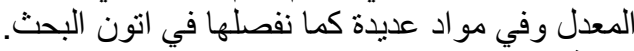

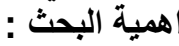

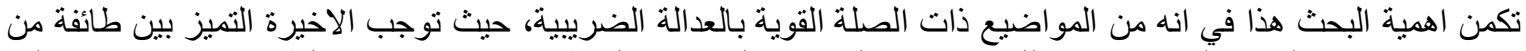

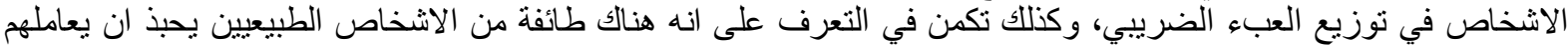

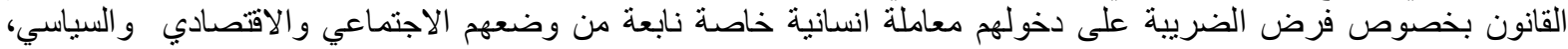

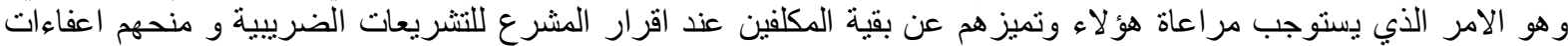

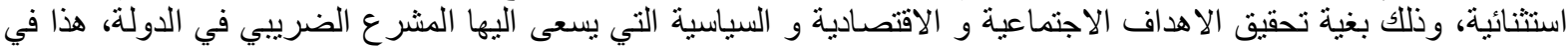
الوقت الذي تعد الاشخاص متساوون المام القانون.

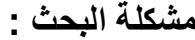

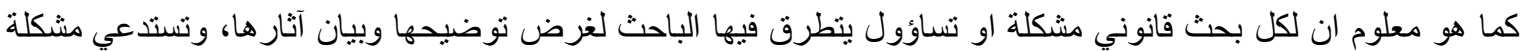

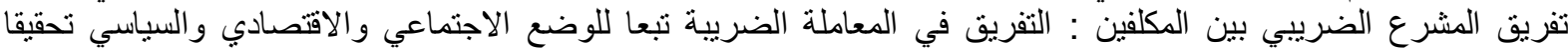

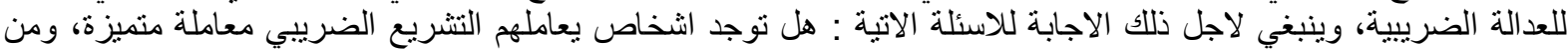
هم هؤلاء؟، وما المقصود بالتفريق و التشخيص في الضريية؟، وماهي اسس واسباب واغر اض هذا التفريق؟، و هل يصطدم ذللك

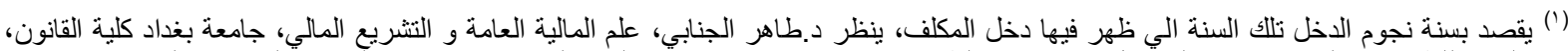

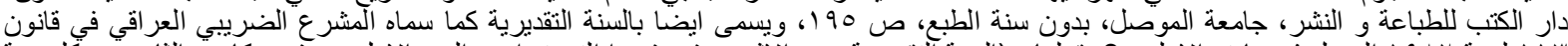

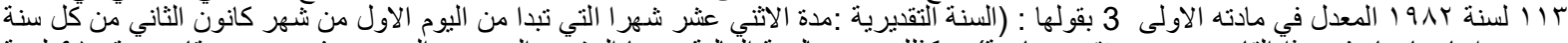

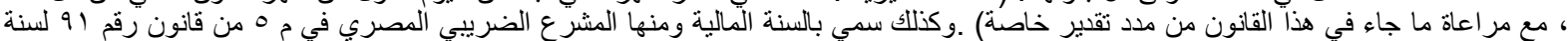

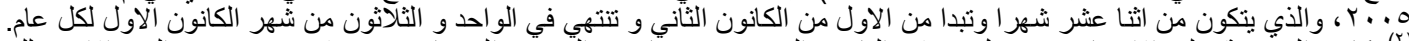

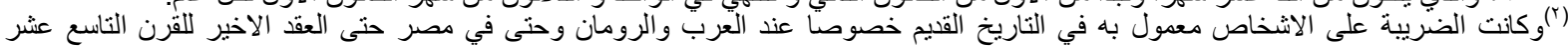

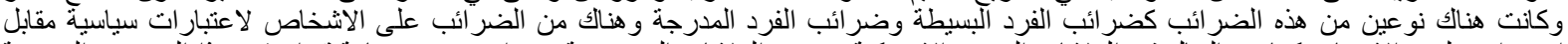

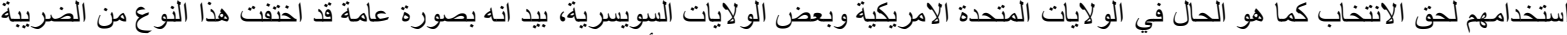

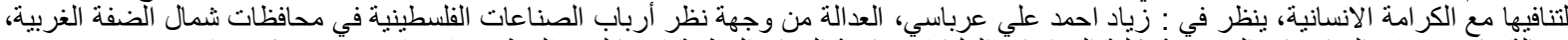

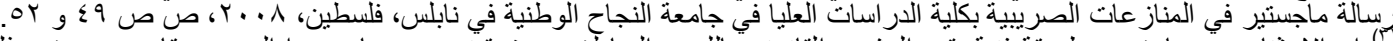

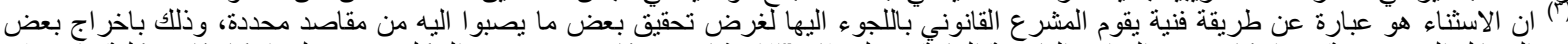

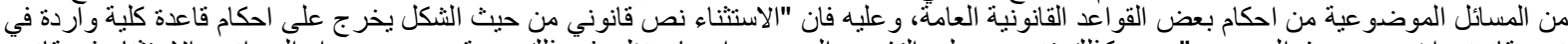

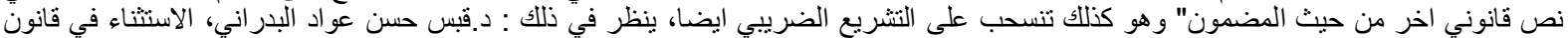

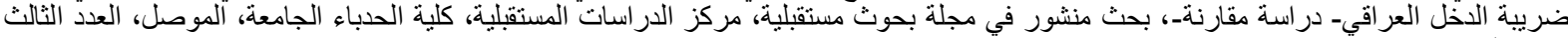




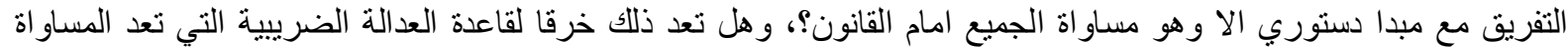

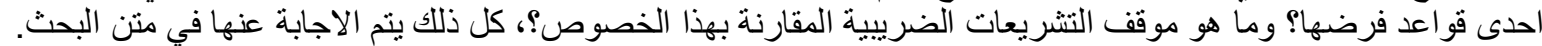

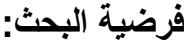

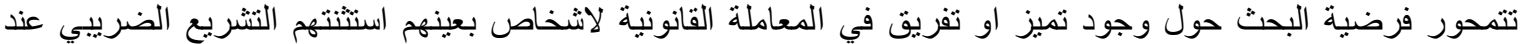

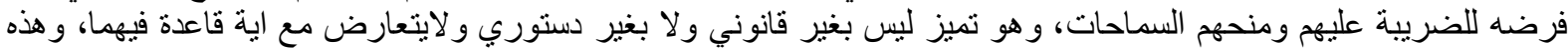

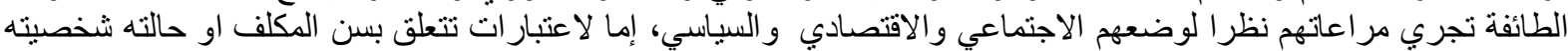

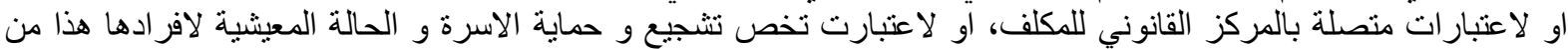

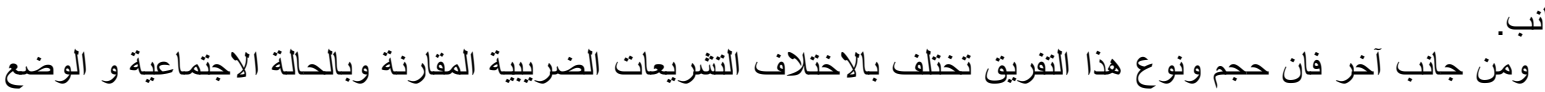

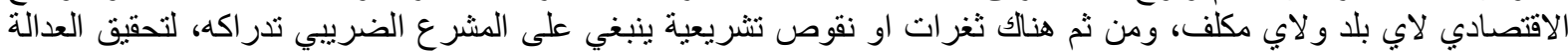

الضرييية قدر الامكان.

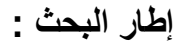

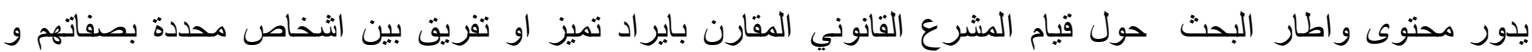

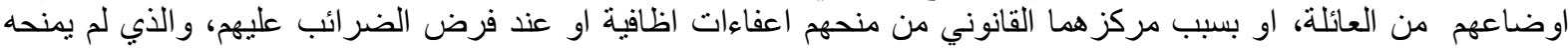

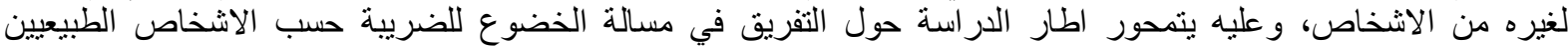

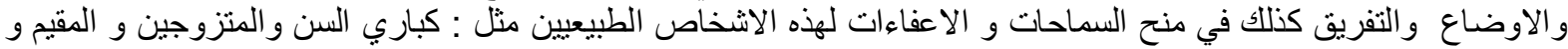

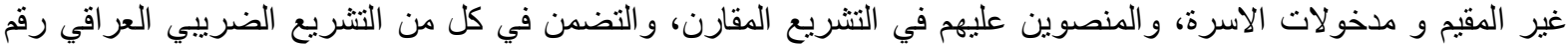

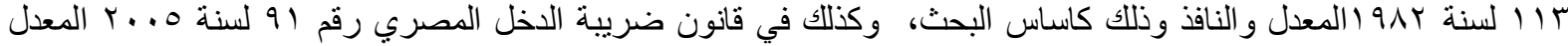

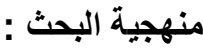

يتم في البحث المتواضع هذا هذا انتهاج اساليب التحليلي و النقدي و المقارن، معتمدين على شرح المتون بدرجة اساسية، وذلك لكي

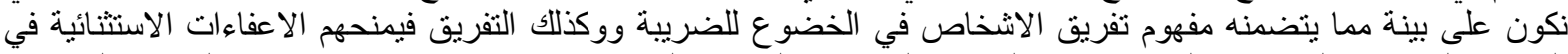

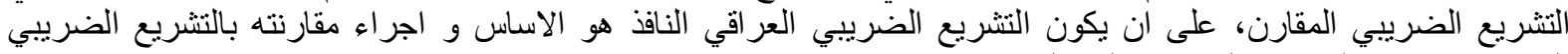
المصري، مشيرا اللى ار اء الفقهاء ان لزئ لزم البحث.

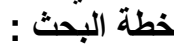

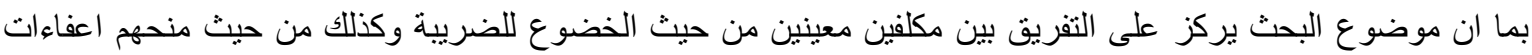

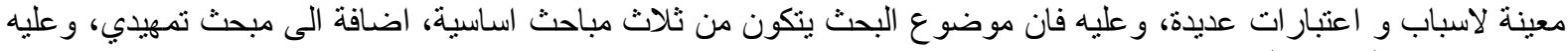

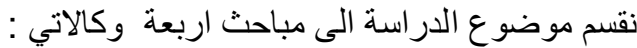
المبحث التمهيدي : الضريبة ومضامينها الاساسية.

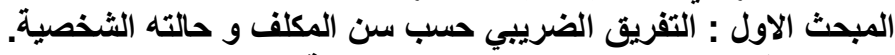

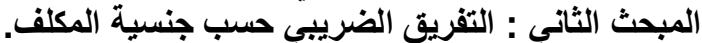
المبحث الثالث : التفريق الضريبي حسب دخل الضئ حنب الاسرة. المبحث التمهيدي

\section{الضريبة ومضامينها الاساسية}

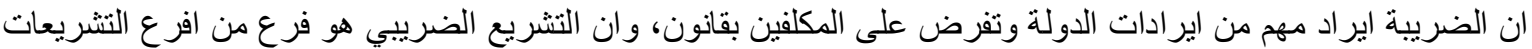

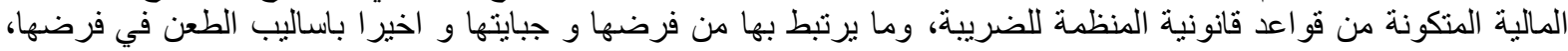

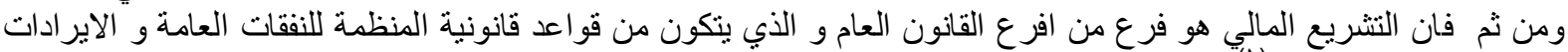

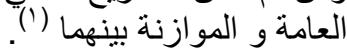

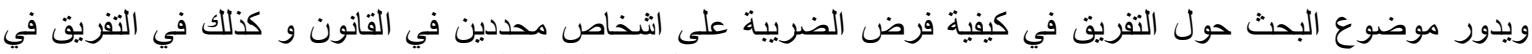

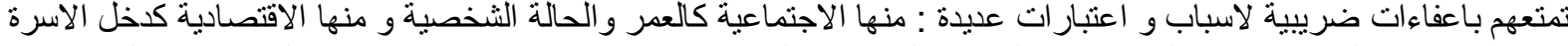

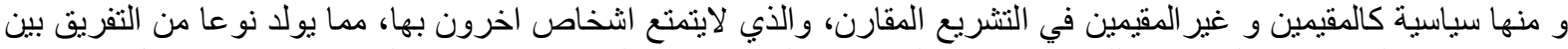

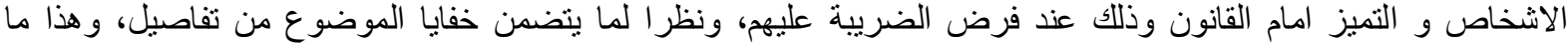

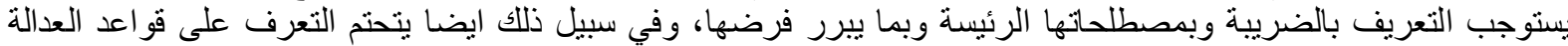
عند فرضها، وبما يفيد منهجية البحث. و عليه يقسم هذا المبحث التمهيدي الى ثلاثة مطالب منتالية : ففي الاول يتم ايراد التئ التعريف بالضريبة وفي الثاني دراسة مبررات فرضها بما يحتاجه البحث، وفي الاخير ينم التركيز على قو اعد العدالة الضريبية.

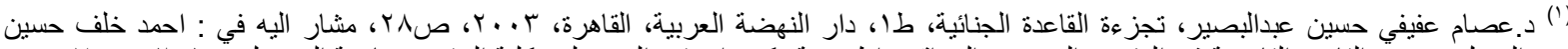

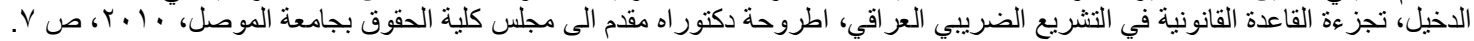




\section{المطلب الاول

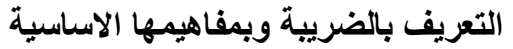

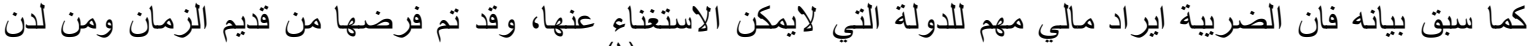

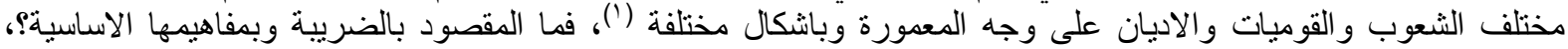
وماذا يعني التفريق حسب عناصر التتخيص؟، وما معنى السماحات و الاعفاءات الضريبية، كل ذلك يتم دراسته في هذا المطلب

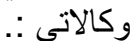

اولا : تعريف الضريبة : تعرف الضريبة من لان الفقيه " جاستون جيسي Gaston Jese" بانها : ( استقطاع نقدي تفرضه الإنه

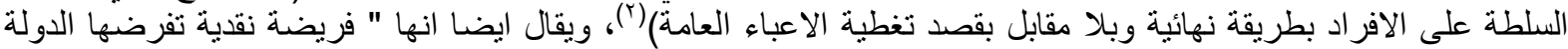

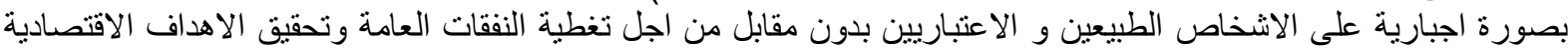

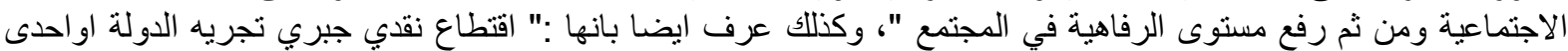

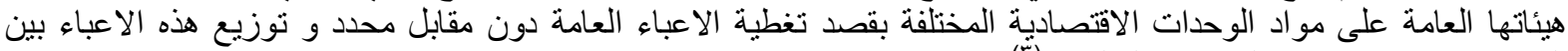

الوحدات الاقتصادية وفقا لمقدرتها التكليفية")(").

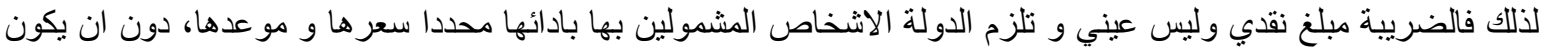

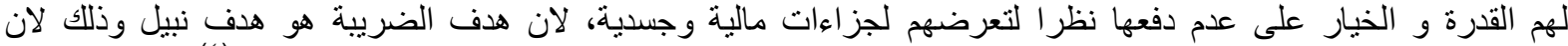

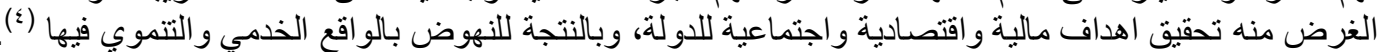

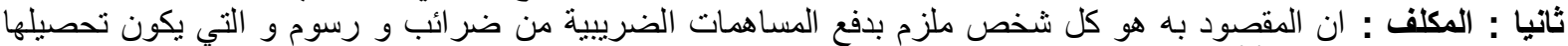

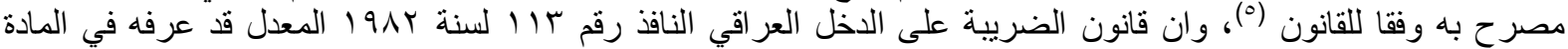

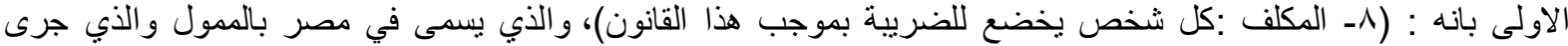

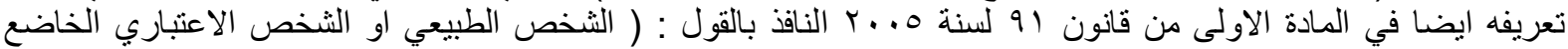

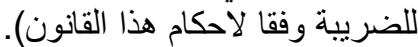

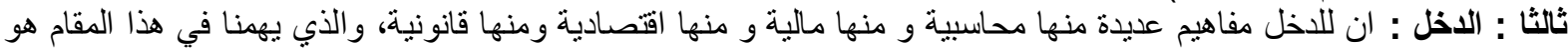

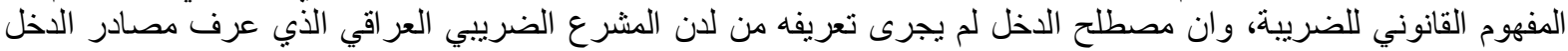

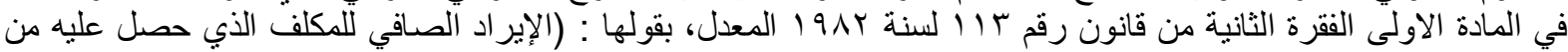

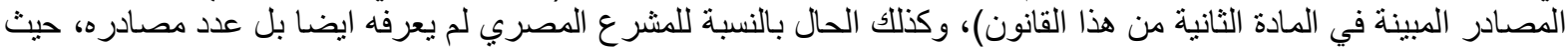

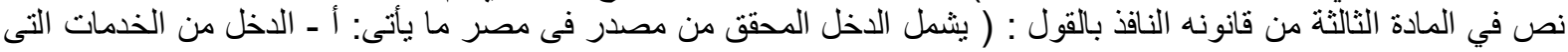

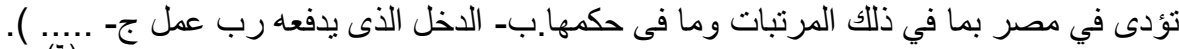

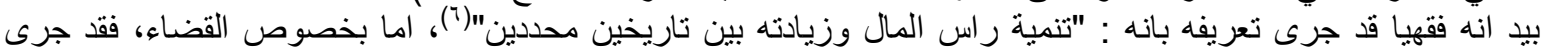

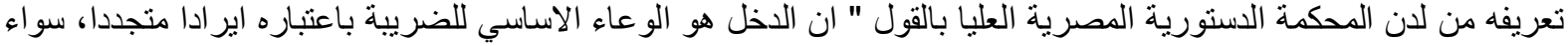

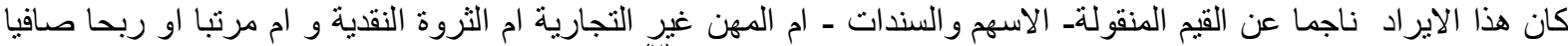

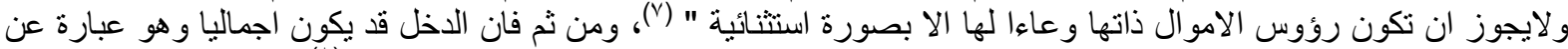

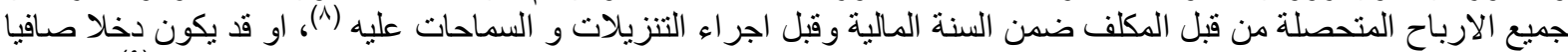

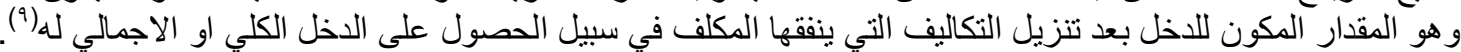

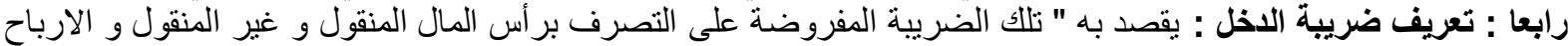

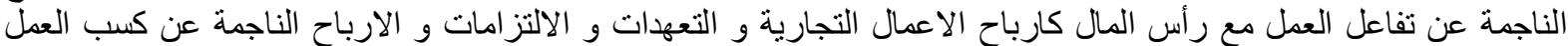

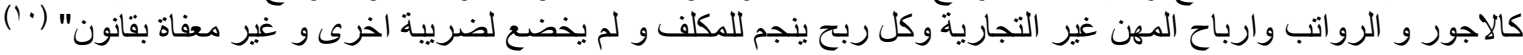

(') وقد اخذت الضريية اشكال عديدة منها ماينتج عن الارض من الحبوب، ومنها ماكان عبارة عن جزء من مشاركة الناس العاديين بمبالغ او اعيان

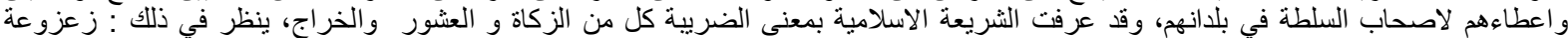
فاطمة، الحماية القانونية الممنوحة للاشخاص الخاص الخاضعين للضريبة، اطروحة دكتوراه في القانون العام مقدمة لكلية الحقوق جامعة ابي بكر بلقابد

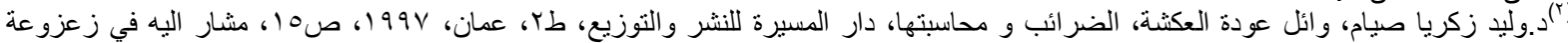

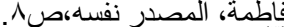

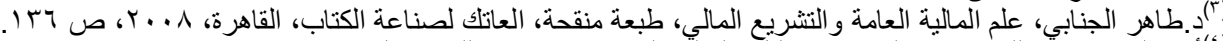

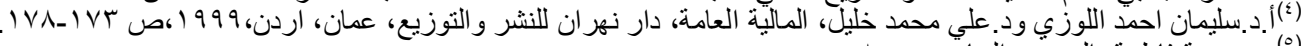

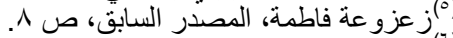

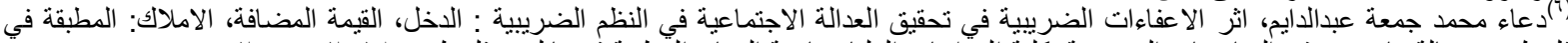

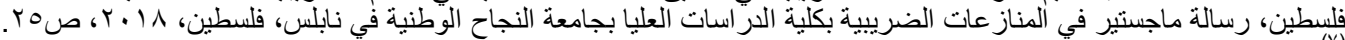

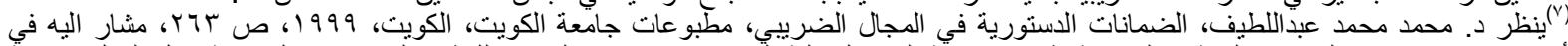

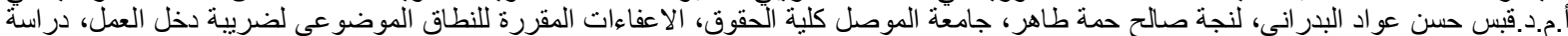

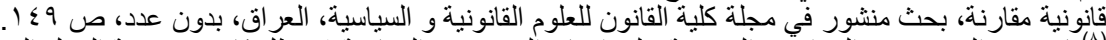

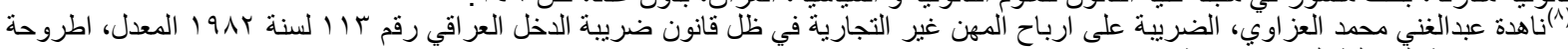

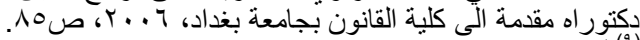

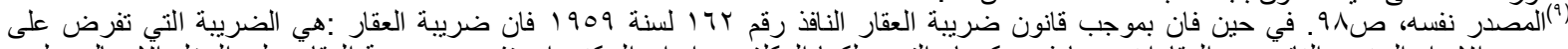
مجموع الاير اد السنوي الناتج عن العقارات و ما في حكمها والتي يملكها المكلف عدا دار السكنى اي تفرض ضرئ ضرية العقار على الدخل الإجمالي وليس الصافي. 


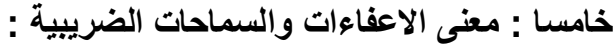

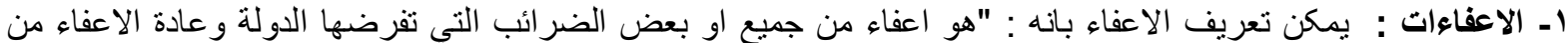

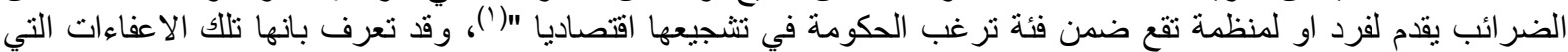

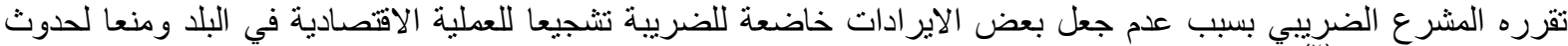

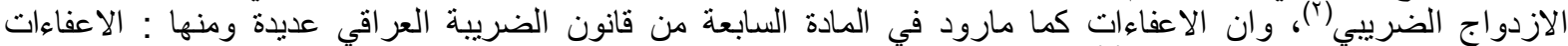

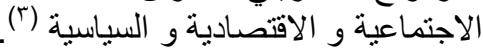

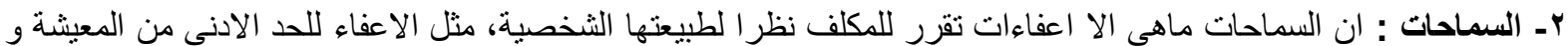

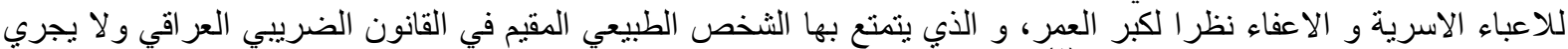

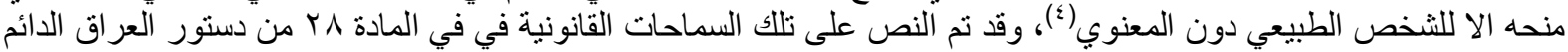

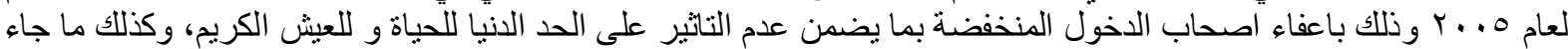

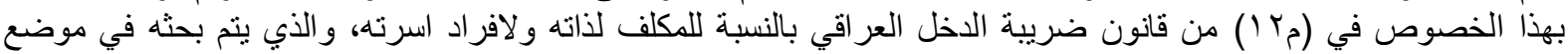
لاحق.

سادسا : : المقصود بالتفريق الضريبي و بعناصر تثخيصها:

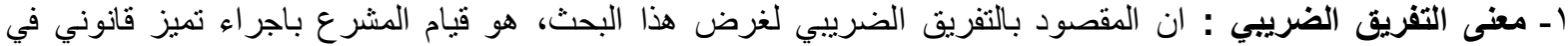

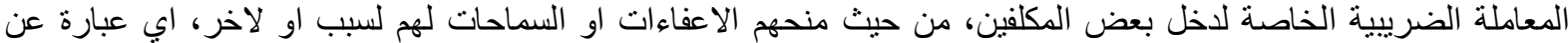

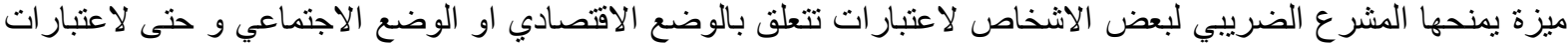

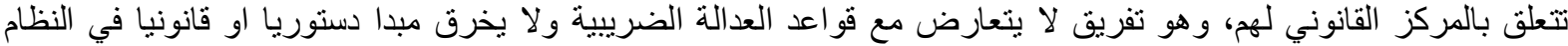
القانوني للإلبل.

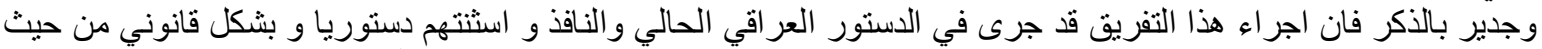

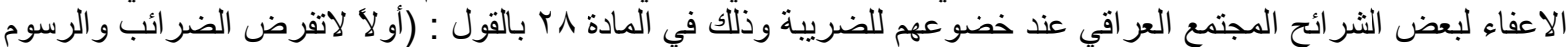

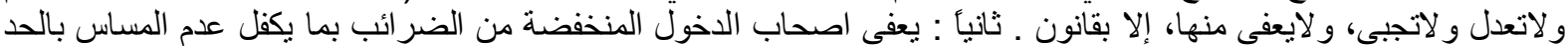

الادنى اللازم للمعيشة، وينظم ذللك بقانون )، و هذا يعني ان التفريق هذا لايتعارض مع المبادئ و القو اعد الدستورية و القانونية.

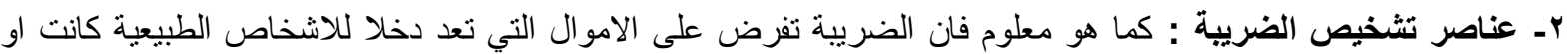

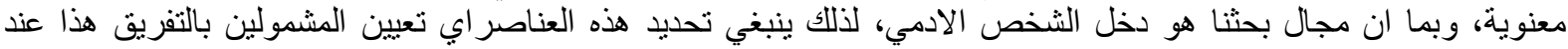

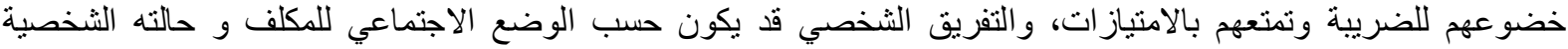

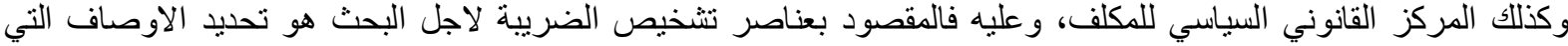

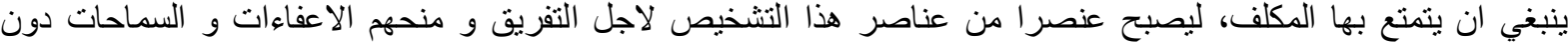

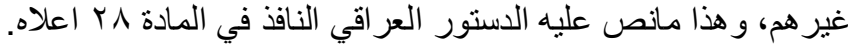
المطلب الثاني ألماه

مبررات فرض الضريبة و قوّ اعد عدالتها

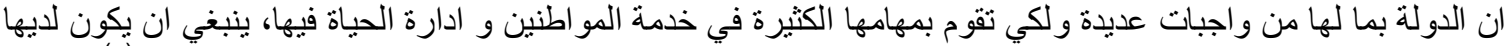

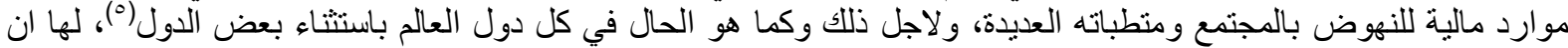

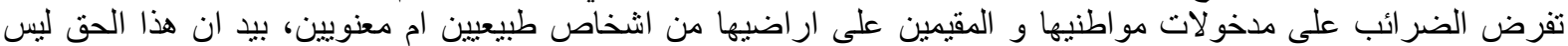

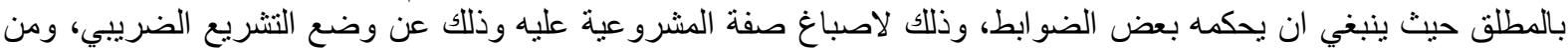

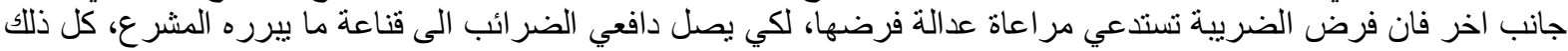

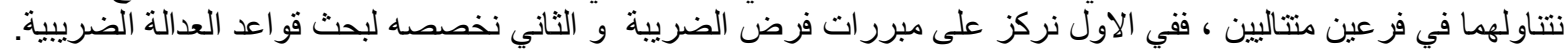

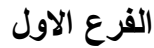

مبررات فرض الضريبة

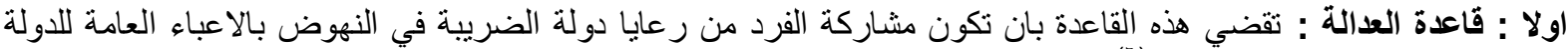

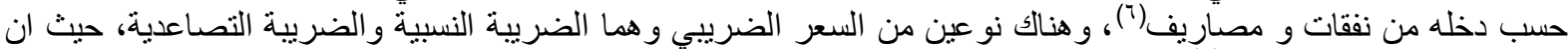

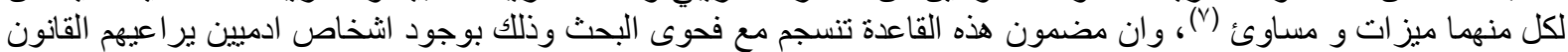
حسب مقدرتهم التكليفية ومساو اتهم امام القانون.

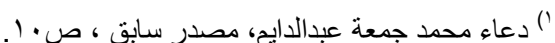

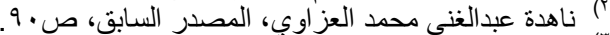

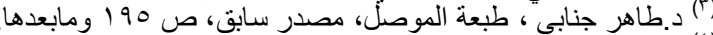

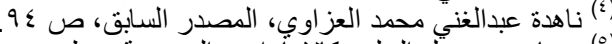

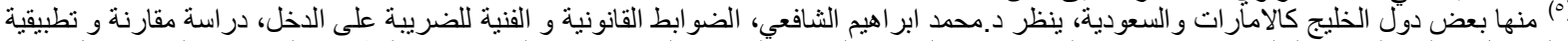

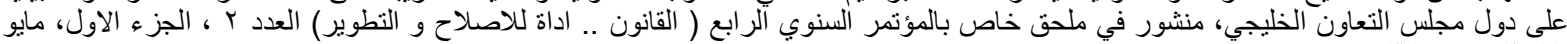

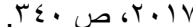

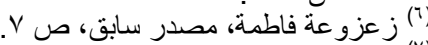

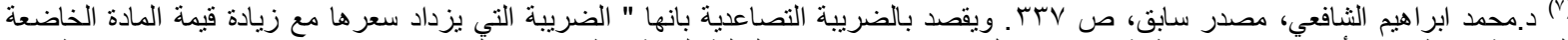

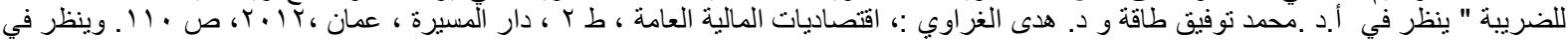


ثانيا : قاعدة الوضوح اواليقين :ومعناها هي ان تكون الضريبة عند فرضها مؤكدة وواضحة و و محددة تحديدا كافية ونافية

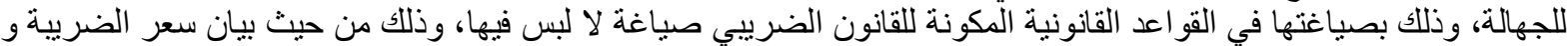

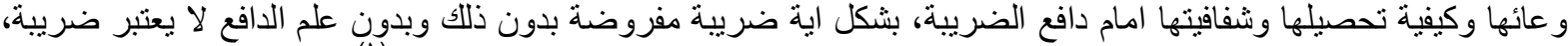

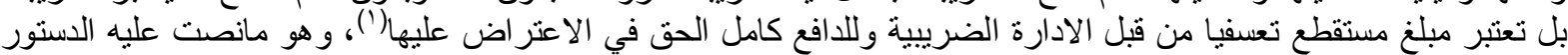

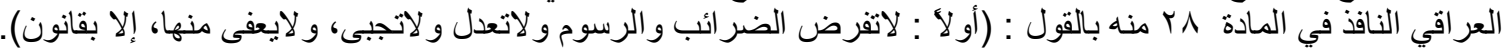

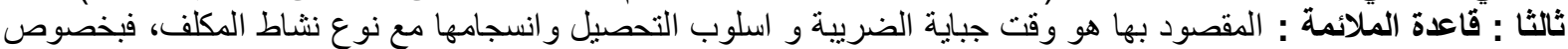

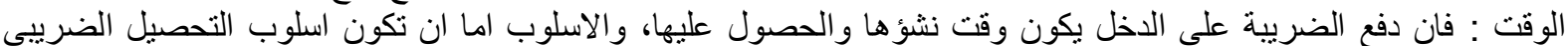

طوعيا او تكون الجباريانا".

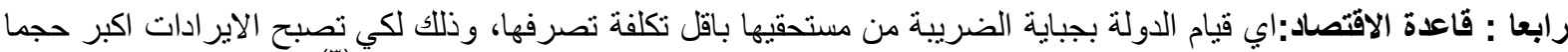

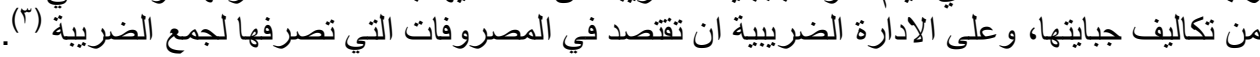
الفرع الثاني

قو اعد العدالة الضريبة الثية

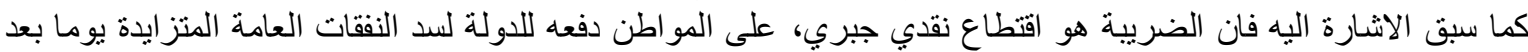

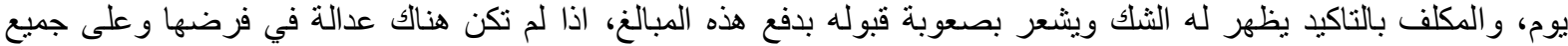

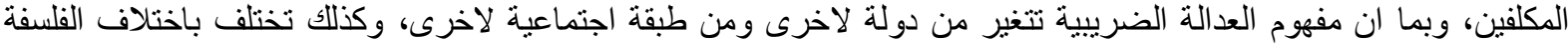
السباسية والاقتصادية والاجتماعية المطبقة في البلد، وهو بذللك مفهوم فلسفي واخلاقي الى جانب اعتباره مفهوما اقتصاديا و

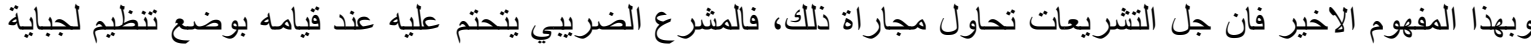

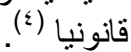

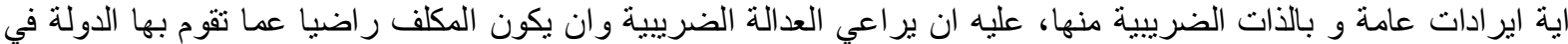

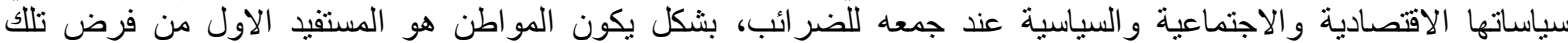

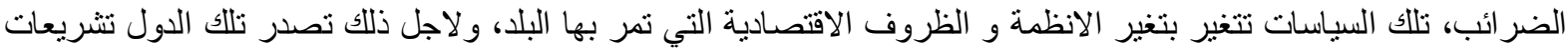

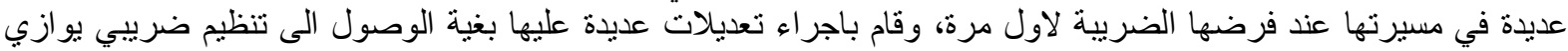

العدالة الضريبية و لا يجافيها.

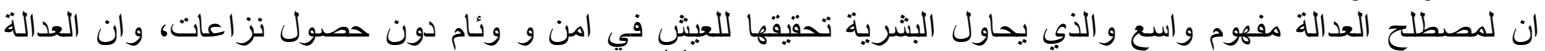

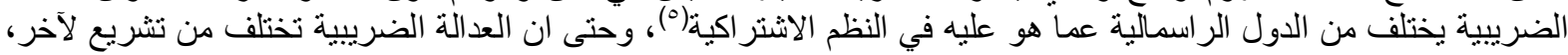

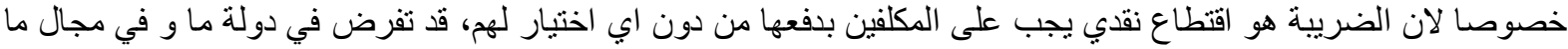

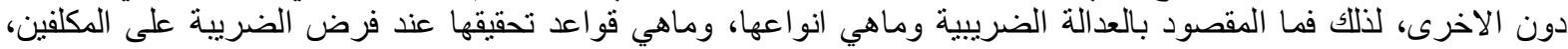

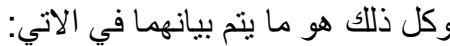

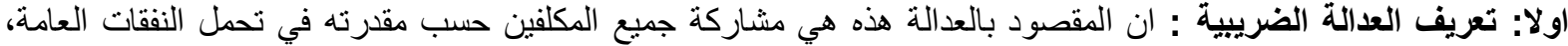

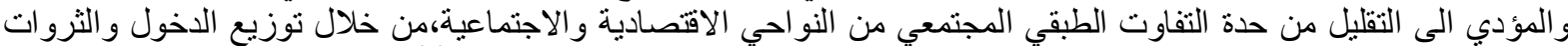

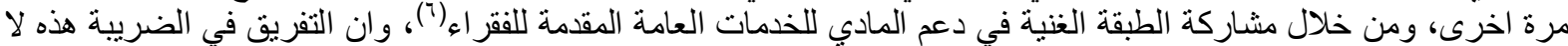

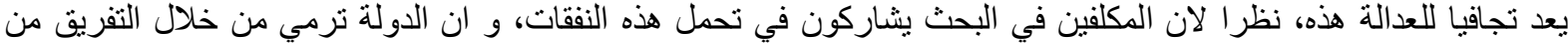

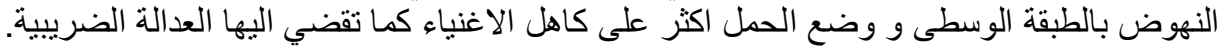

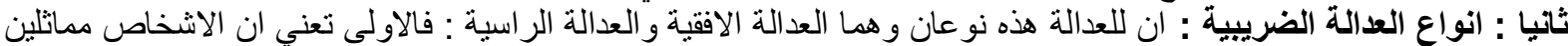

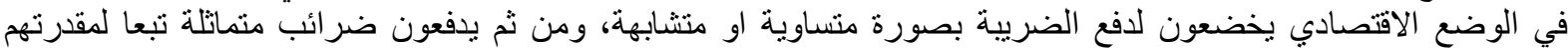

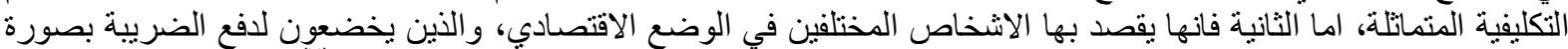

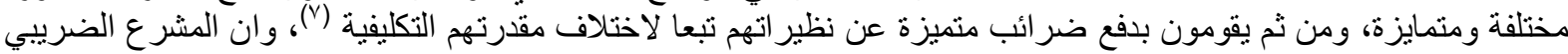

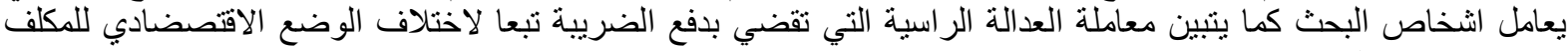

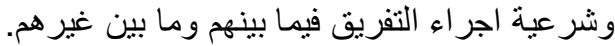

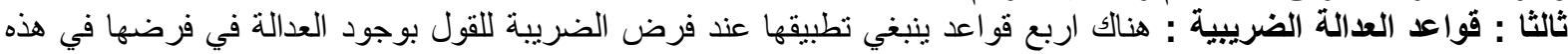

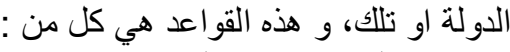

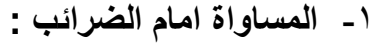

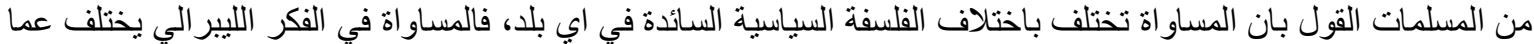

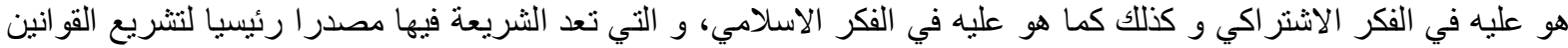

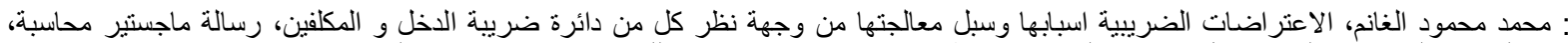

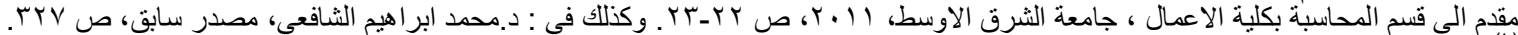

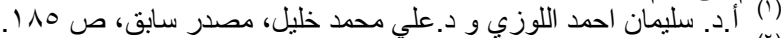

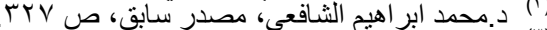

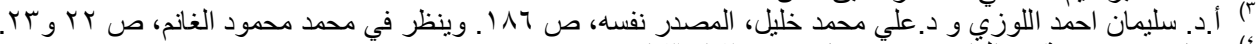

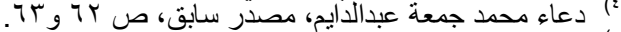

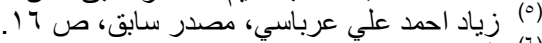

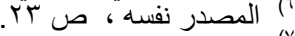

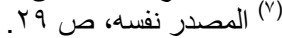


في بلادنا وخصوصا العر اق، حيث اكد الثريعة الاسلامية الغراء(') على المساو اة بين الافراد خصوصا في دفع الزكاة و التي تعنبر نو عا من الضر ائب ينبخي على المقيمين في الدار الاسلامية الإنية دفعها.

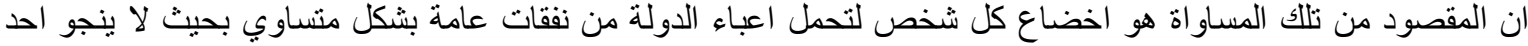

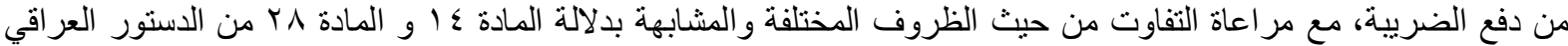

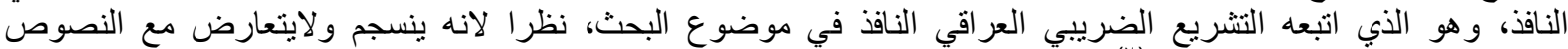

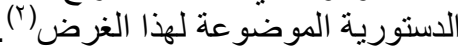

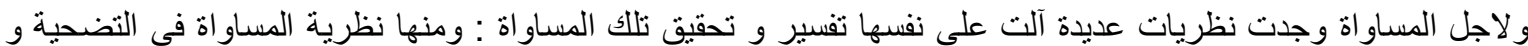

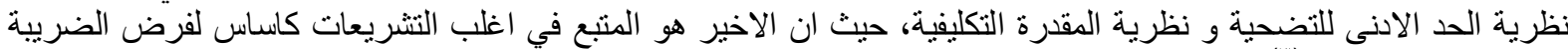

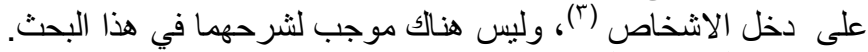

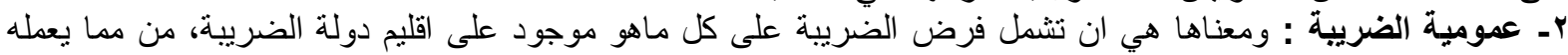

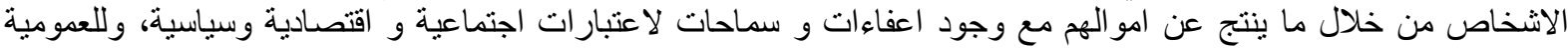

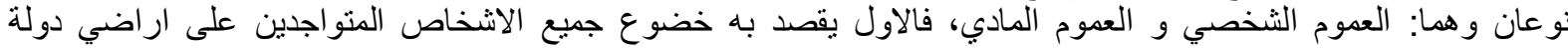

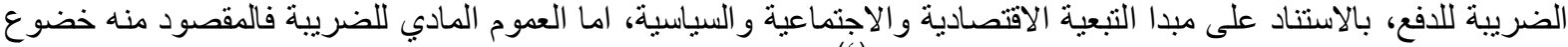

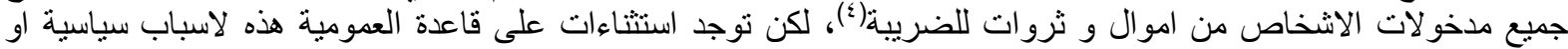

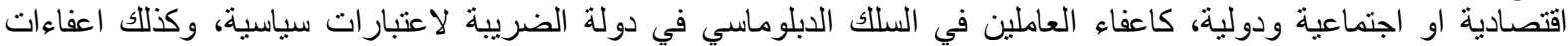

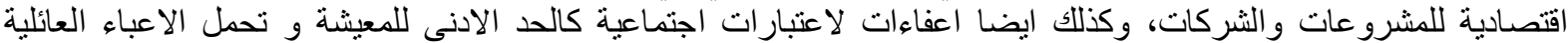
للاشخاص الطبيعيين.

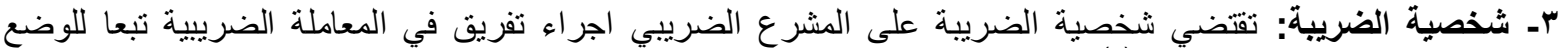

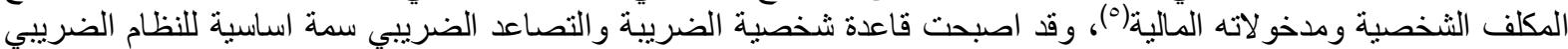

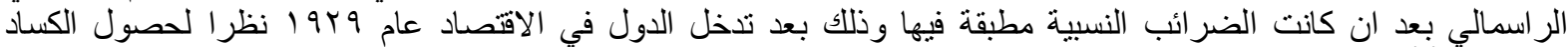

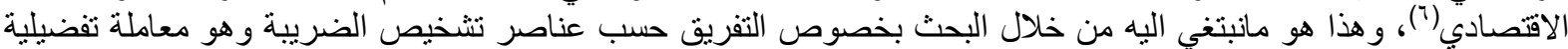
لاعتبار ات عديدة. ــ عدم ازدواجية الضريبة : ان المقصود بالازدواج الضريبي هو " فرض الضريبة لإنية لاكثر من مرة على المال نفسه الخاضع

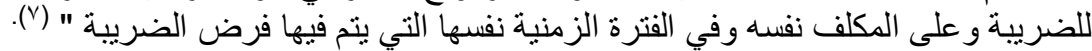

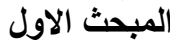

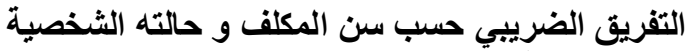

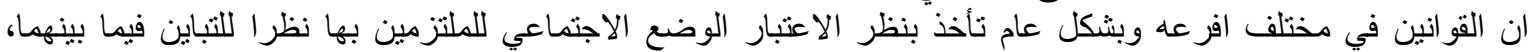

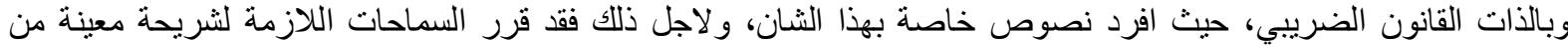

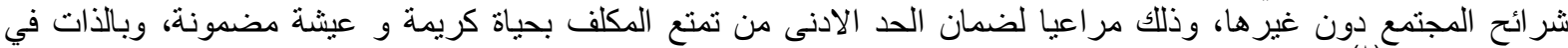

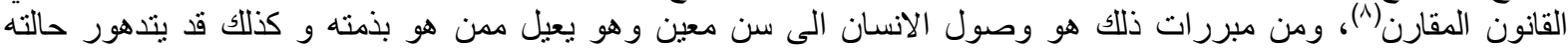
الصحية على الاغلب، او قد يكون بذون معيل او معيلة وقد كثرت احتياجاته والتز اماته المالية، وبالمقابل قلة وندئ وندرة موارده للقيام

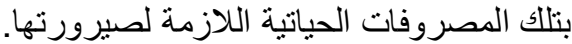
ولذلك نقسم المبحث اللى مطلبين اثثين:اولهما للبحث في التفريق الضريبي لمر اعاة المكلف حسب سنها، و الثاني يتم دراسة التفريق الضريبي حسب حالته الثخصية، وسنتناول بين طيات المطلبين اتجاه التشريع المقارن لإن حول ذلك.

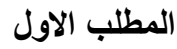

\section{التفريق الضريبي حسب سن المكلف المكلف}

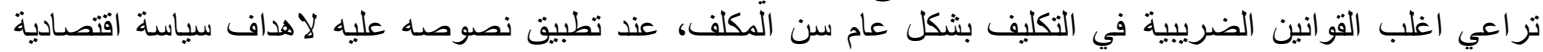

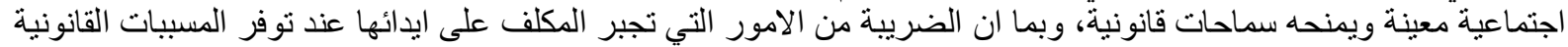

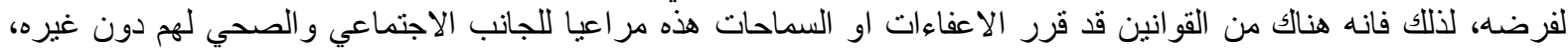
وذللك عند وصولهم سنا معينا من العمر. لأنه

(1) قالي عبدالقادر، العساو اة بين القوانين الوضعية و الثريعة الاسلامية، مذكرة نيل شهادة ماجستير في العلوم القانونية مقدم الى كلية الجقوق والعلوم

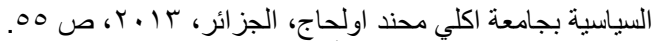

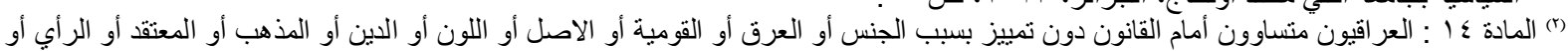

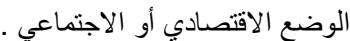

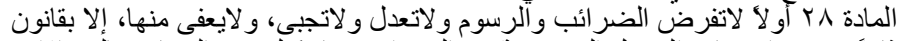

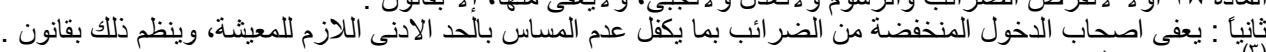

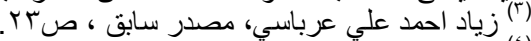

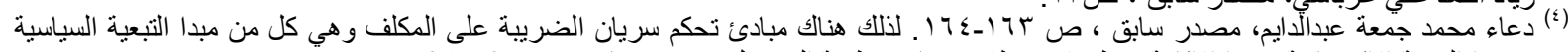

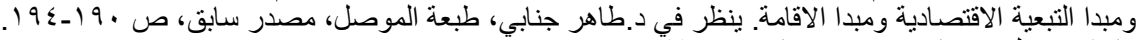

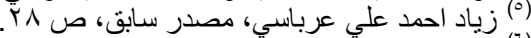

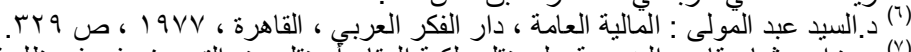

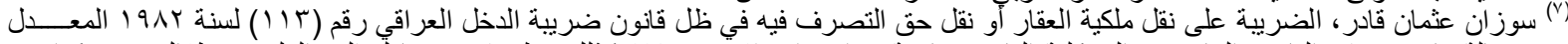

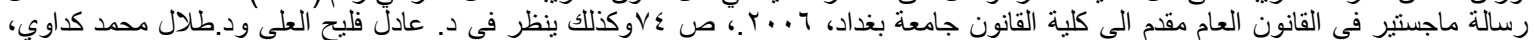

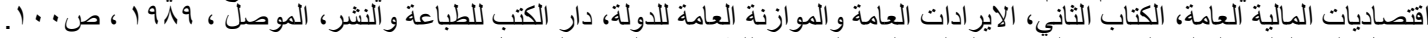

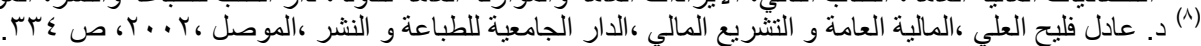


ويمكن تعريف سن المكلف و حالته الصحية بانه العمر الذي يصل اليه الانسان ليس بمقدوره القيام بالعمل وجمع الدخل كما

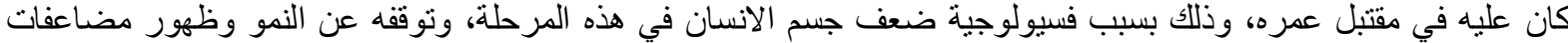

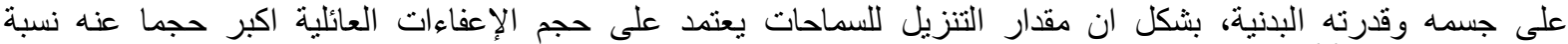

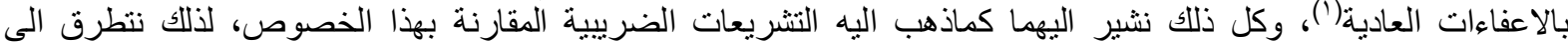

\section{الفرع الاول}

الموضوع في فرعين متتاليين.

\section{اتجاه التشريع الضريبي العراقي الاولي والئي}

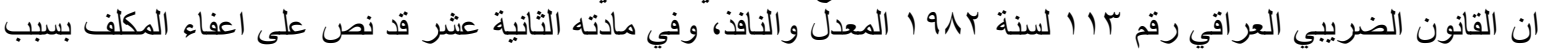

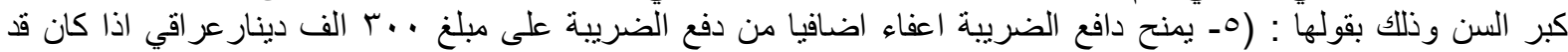

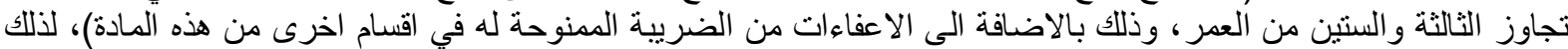

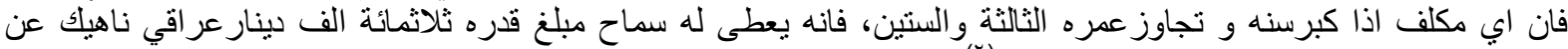

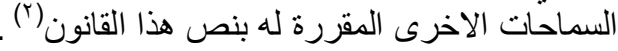

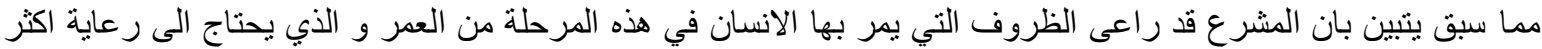

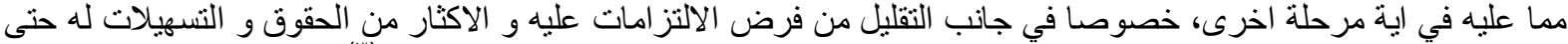

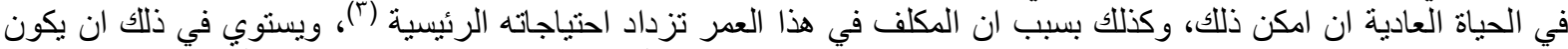

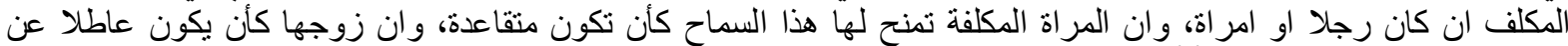

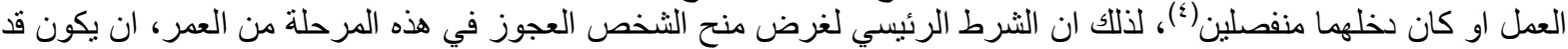

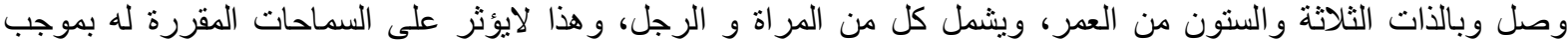

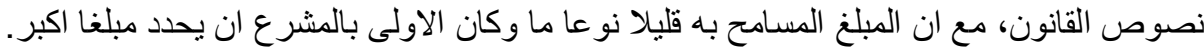

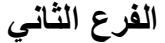

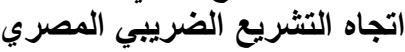

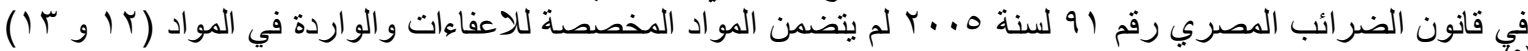

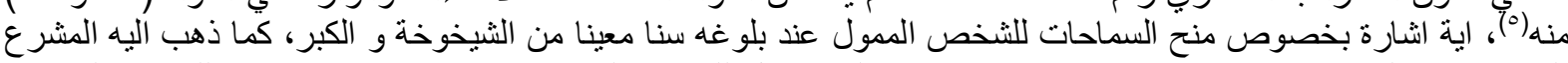

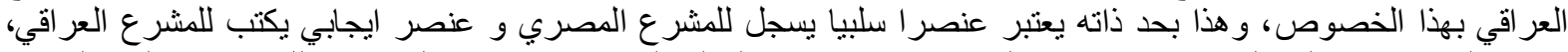

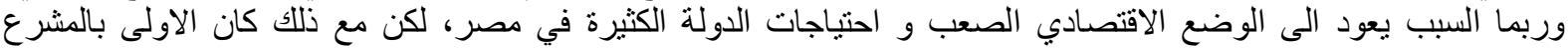

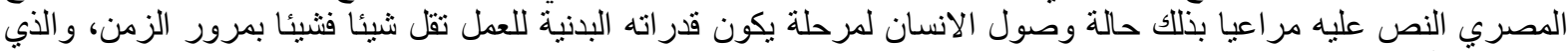

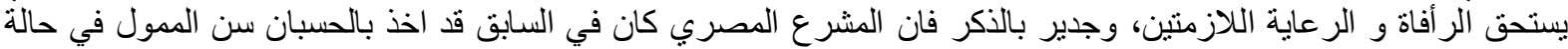

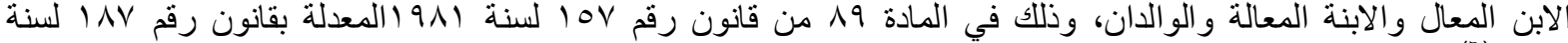

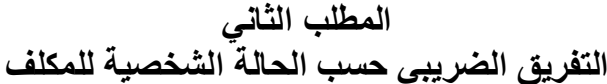

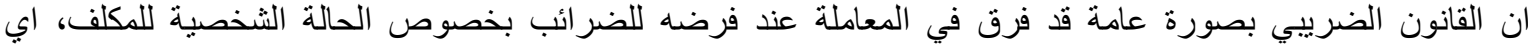

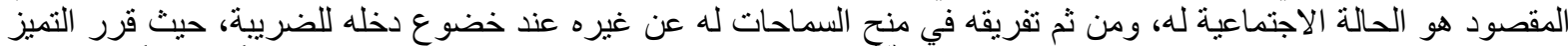

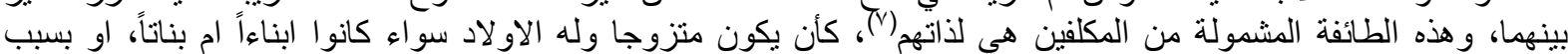
انقطاع الر ابطة الزوجية او انتهاءها، كان يكون المكلف اعزبا او ارملة او مطلقة، وكل ذللك يتوقف على لأل فلسفة النظام الاجتماعي

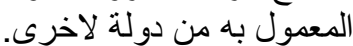

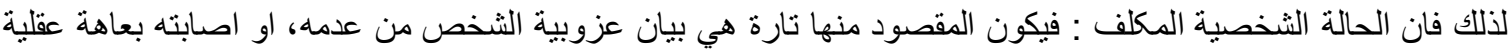

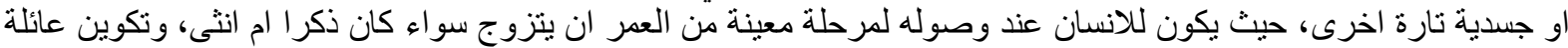

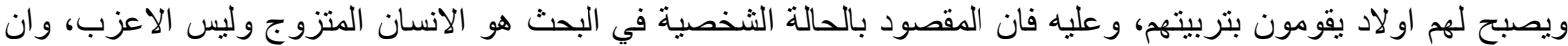

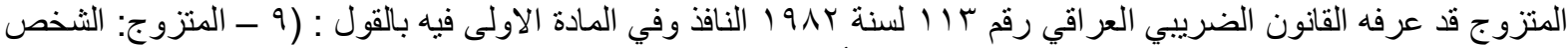
الطبيعي المرتبط بعقد زو اج شر عي دائم تقره القو انين على أن يكون الزوجان في قيد الحياة ولم يقع بينهما طلاق او الفتر اق).

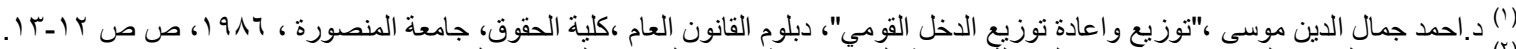

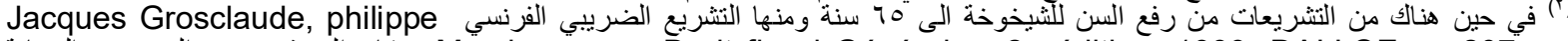

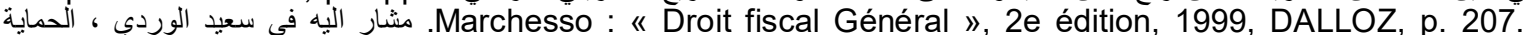

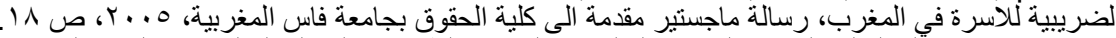

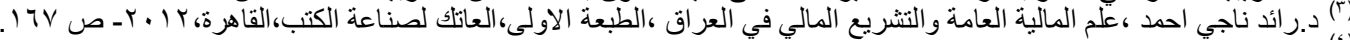

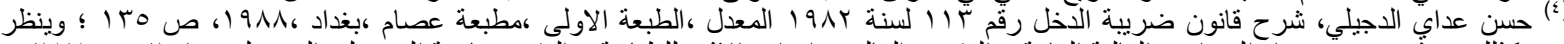

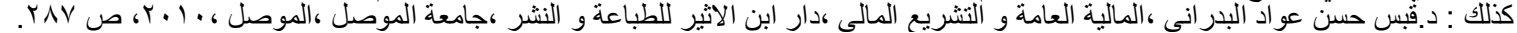

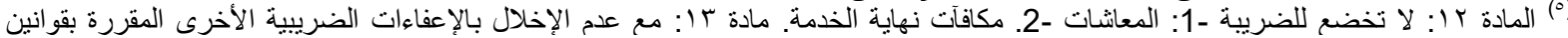

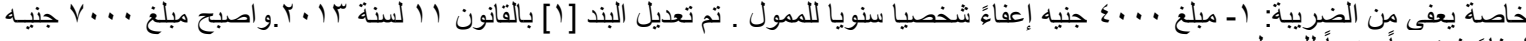

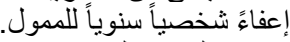

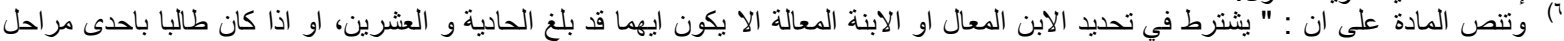

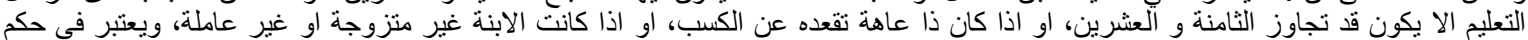




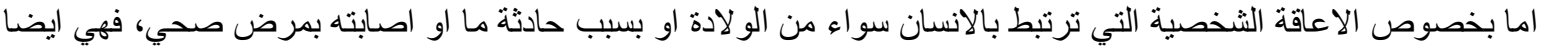

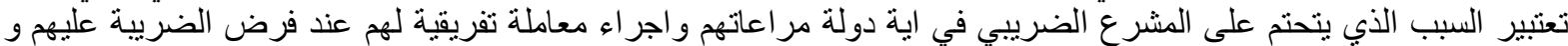

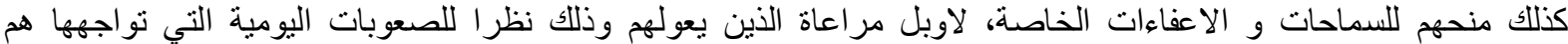

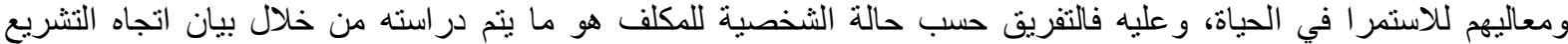
الضريبي المقارن حوله وفي فر عين مستقلين.

\section{الفرع الاول}

\section{اتجاه التشريع الضريبي العراقي}

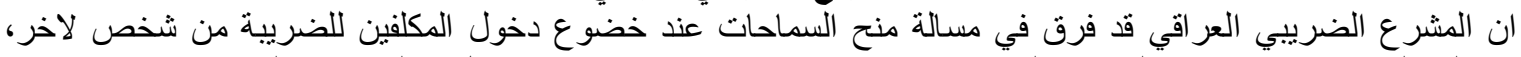

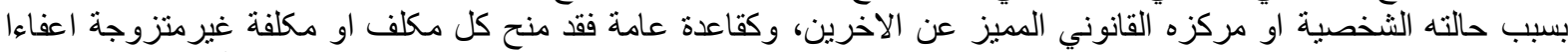

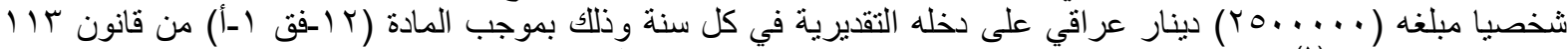

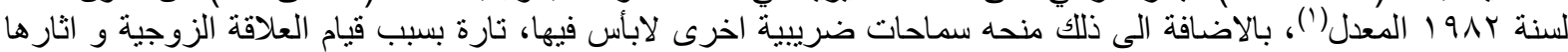

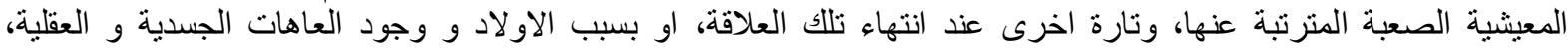

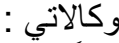

اولاً : السماح بسبب الرابطة الزوجية : اعطى المشرع العر اقي سماحا قانونيا للمكلف المتزوج اضافة الى سماحه الثخصي

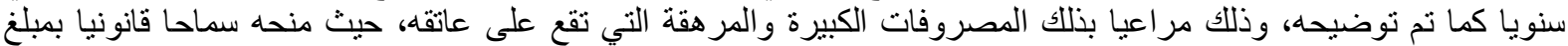

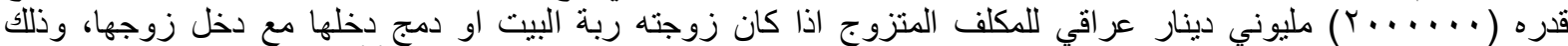

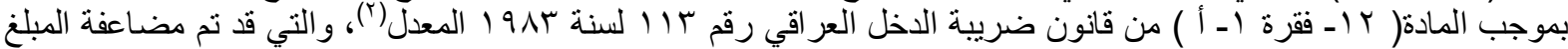

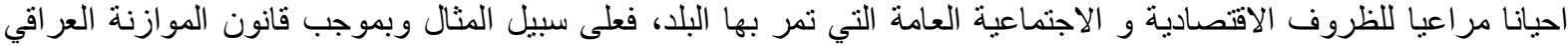

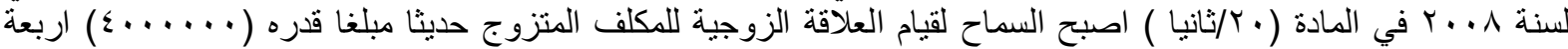
ملايين دينار .

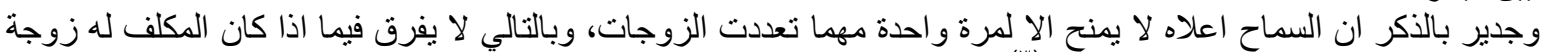

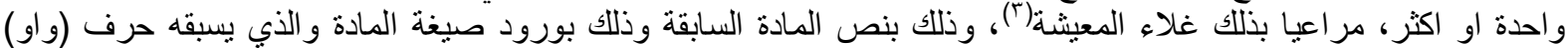

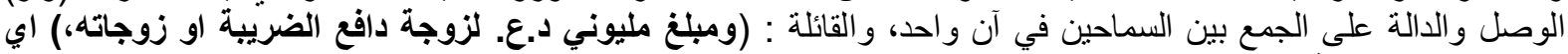

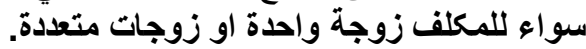

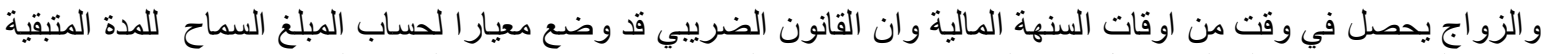

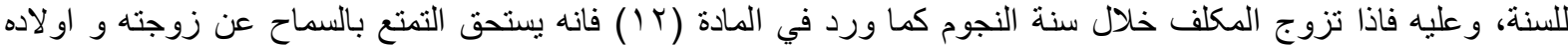

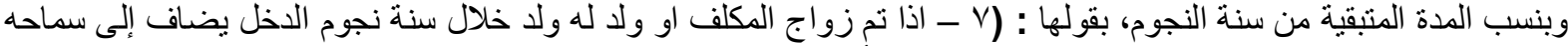

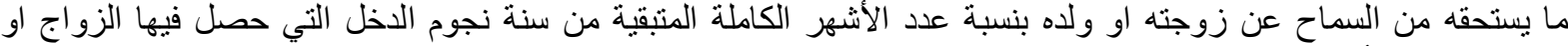

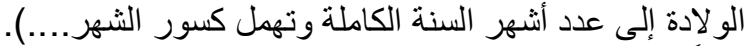

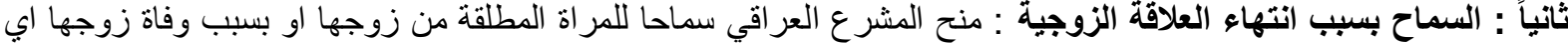

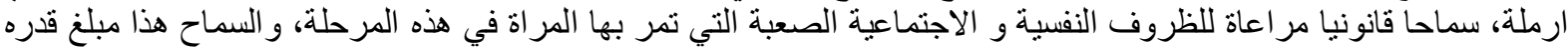

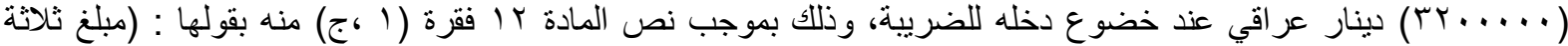

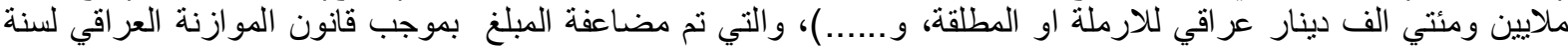

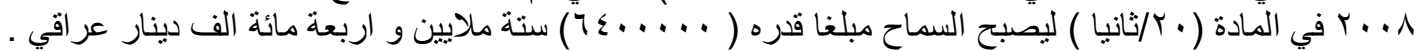

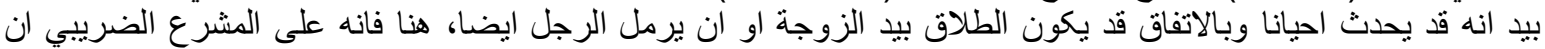

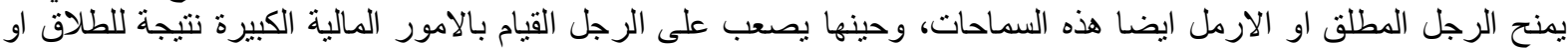

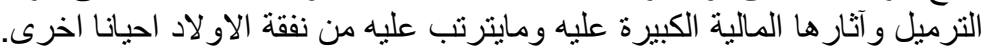

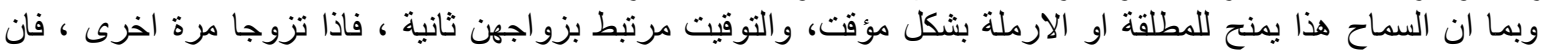

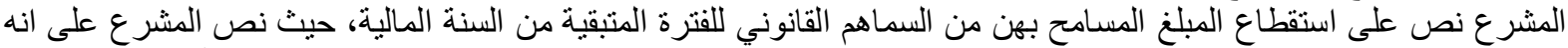

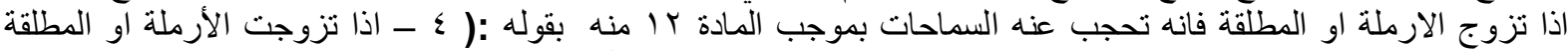

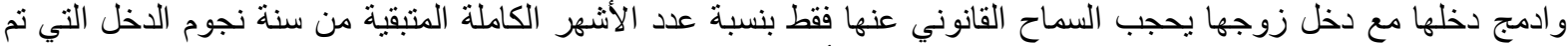

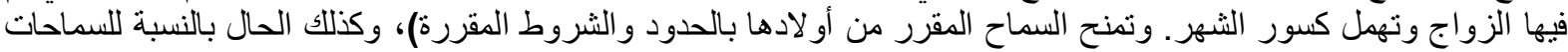

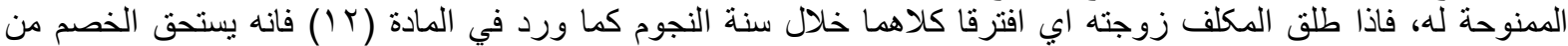

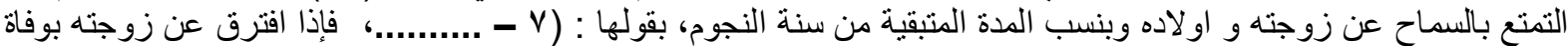

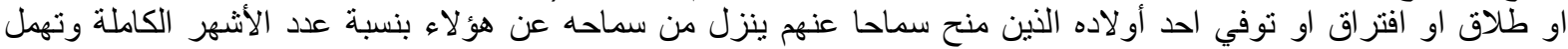

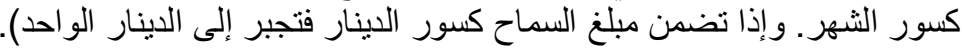

(1) تتص الفقرة الاولى من هذه المادة بالقول : (بمنح الثخص المقيم الإعفاءات التالية من ..... ا ـ مبلغ مليونين وخمسمائة ألف دينار عر اقي د.ع لدافع

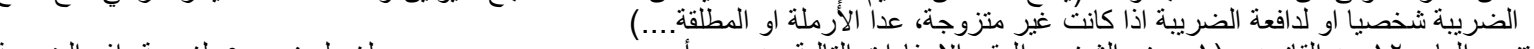

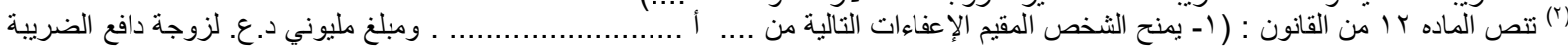

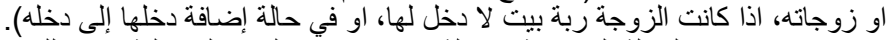

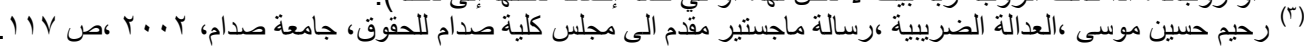




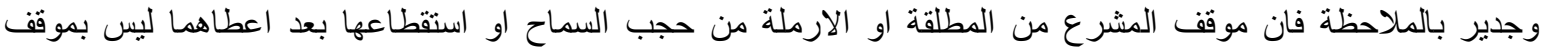

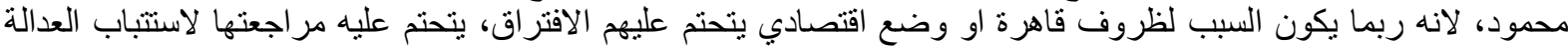
الضرييية فيما بين المكلفين.

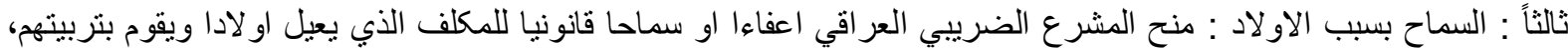

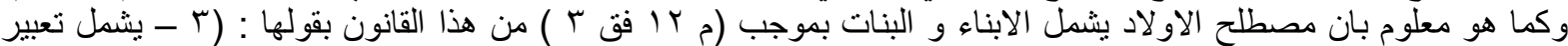

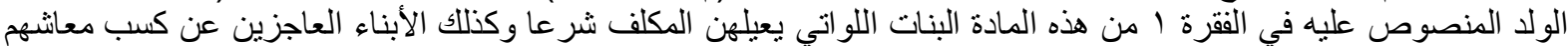

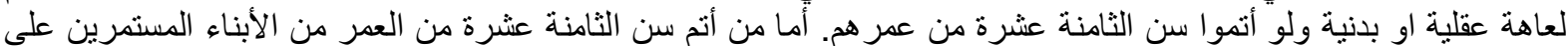

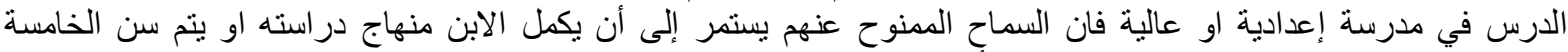

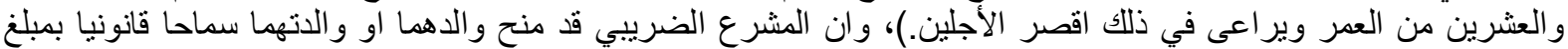

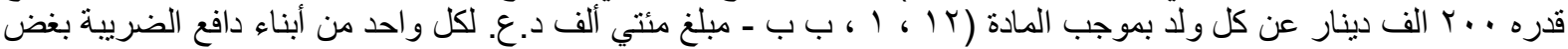

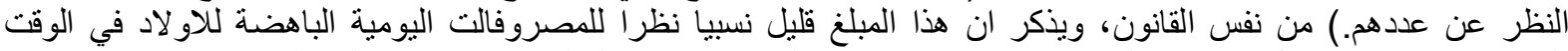

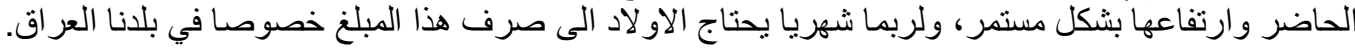

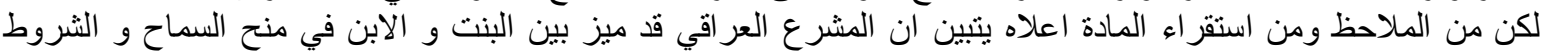

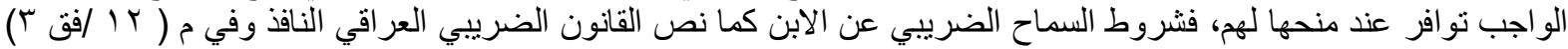

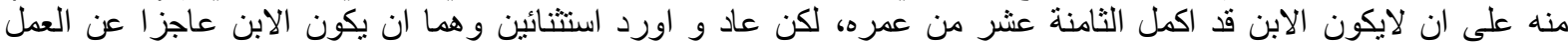

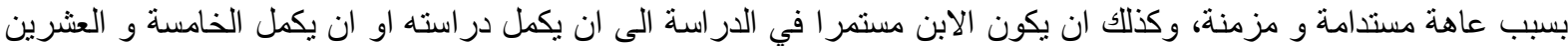

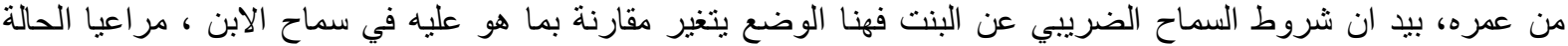

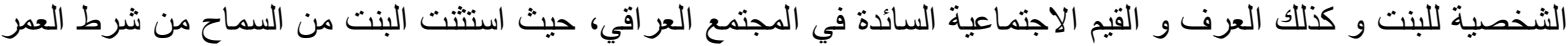

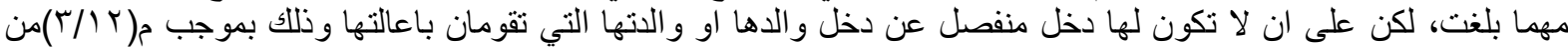

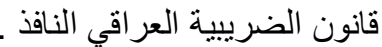

\section{الفرع الثاني}

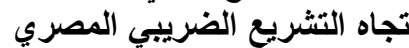

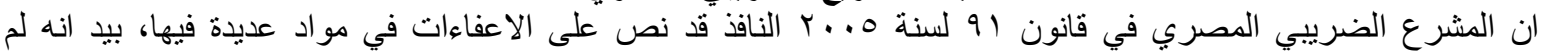

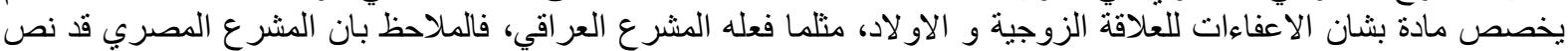

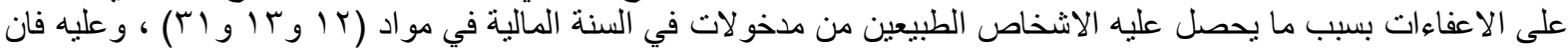

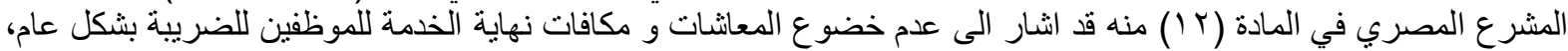

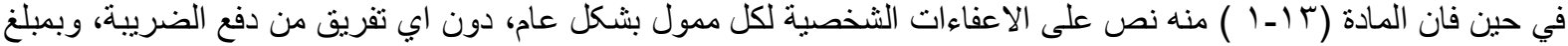

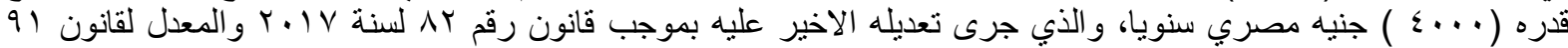

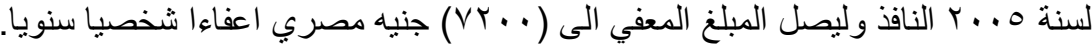

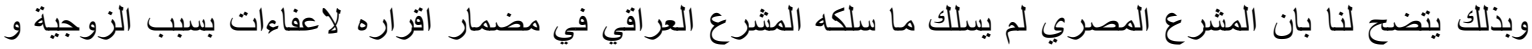

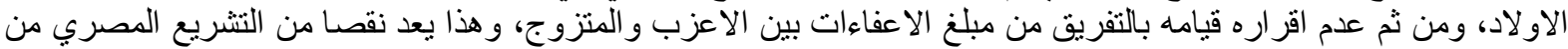

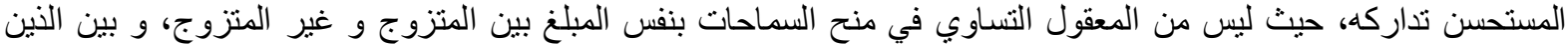

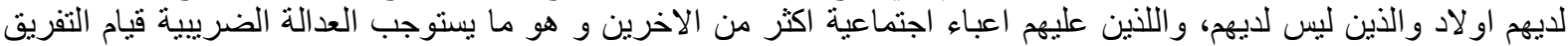

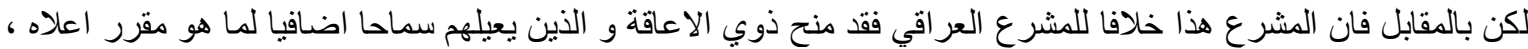

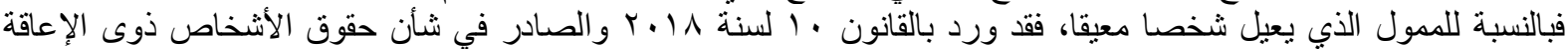

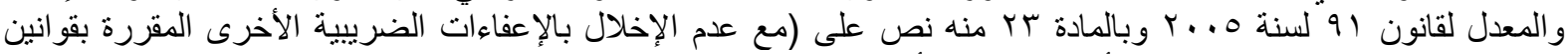

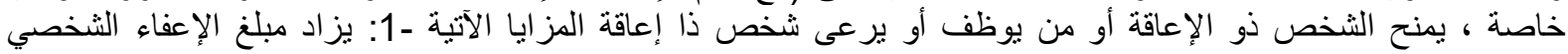

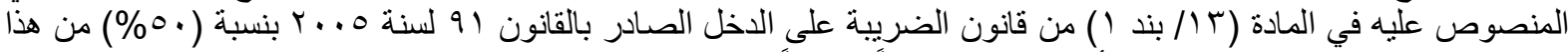

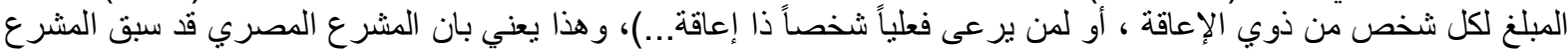

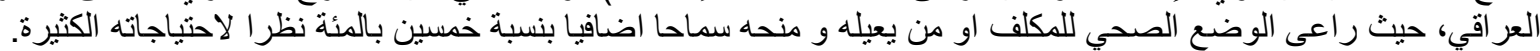

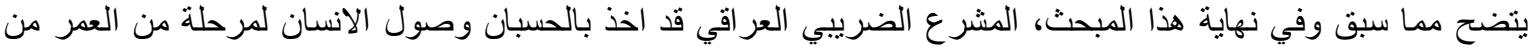

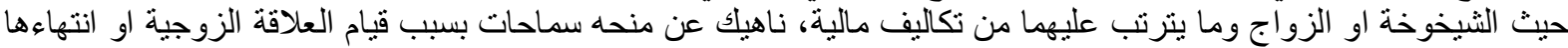

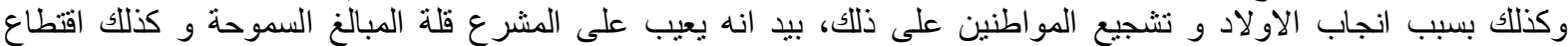

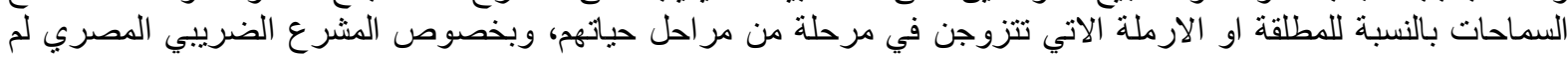

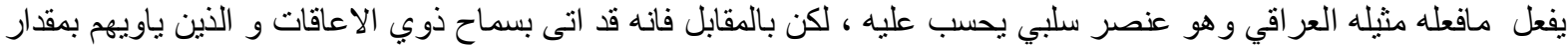
كافي وهو مالم يفعله العر اقي بهذا الثنكل.

\section{المبحث الثاني

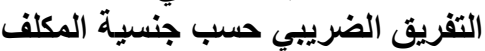

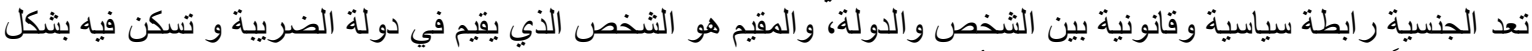

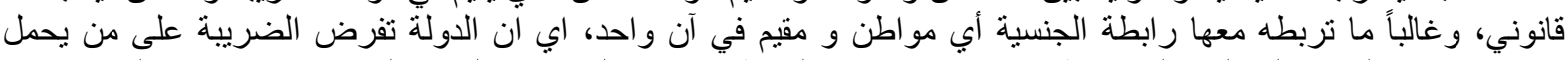

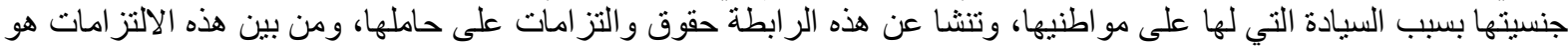




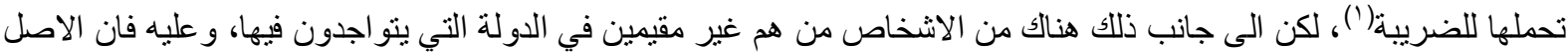

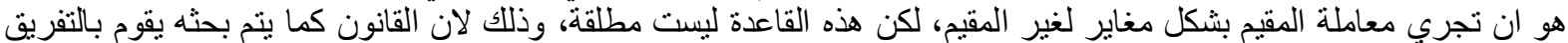

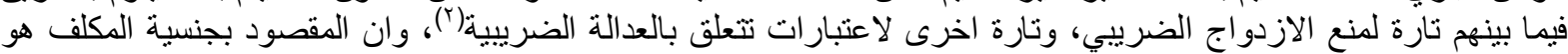

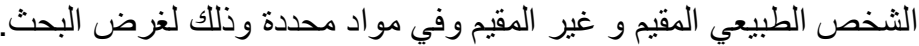

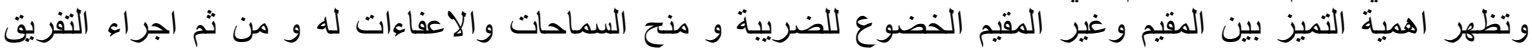

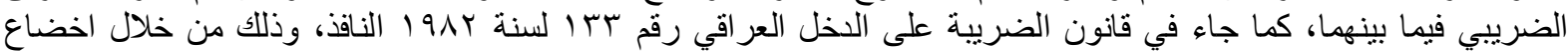

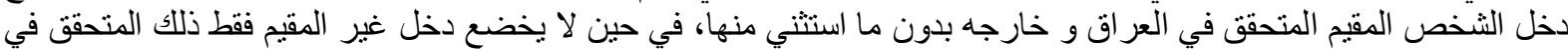

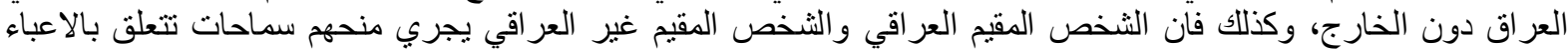

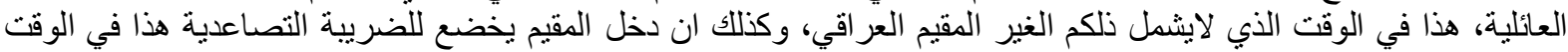

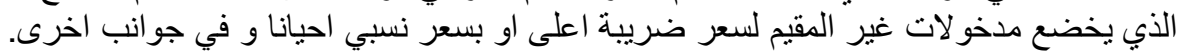

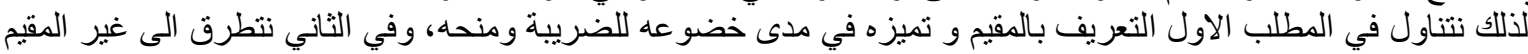

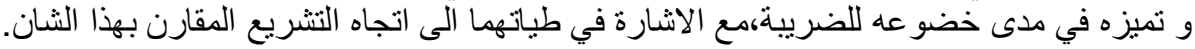
المطلب الاول المباه

\section{التعريف بالمقيم و مدى خضو الاوله للضريبة}

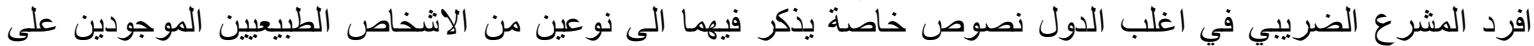

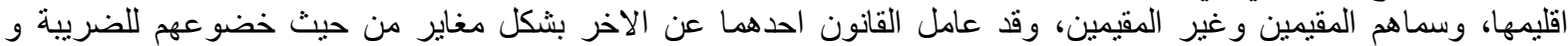

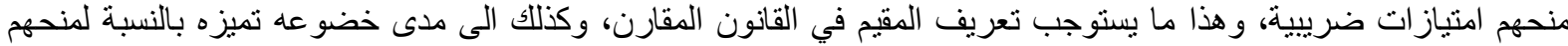
من حيث خضو عهم للضريبة، وذللك في فر عين متتاليين وكالاتي :

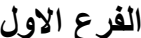

\section{تعريف المقيم في التشريع الضريبي المقارن}

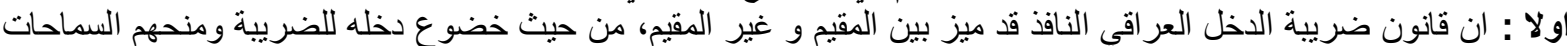

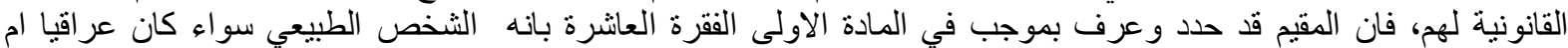

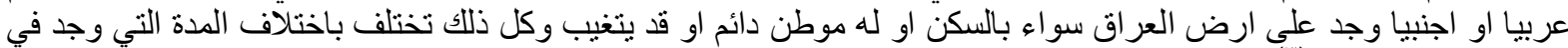

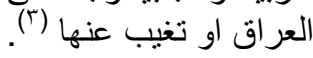

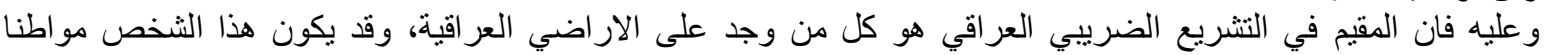

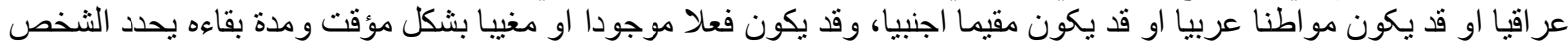

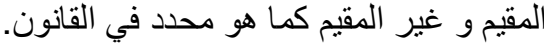

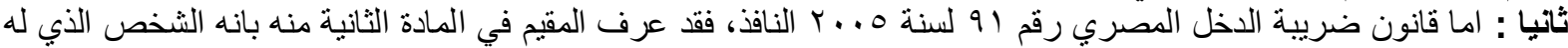

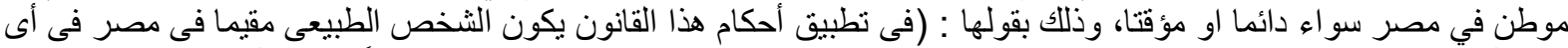

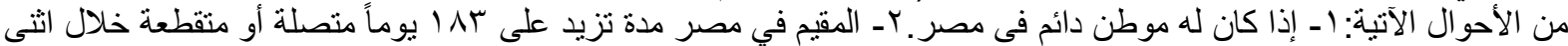

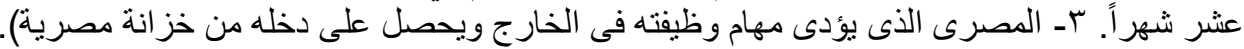

\section{خضوع المقيم للضريبة في التشريع الضرئي الفي القارن}

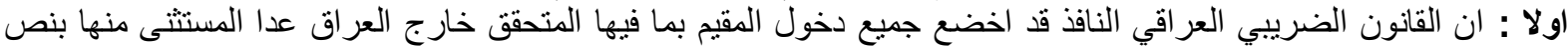

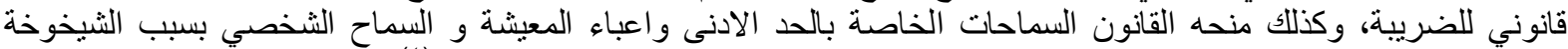

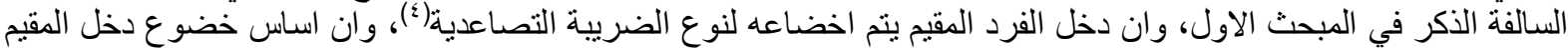

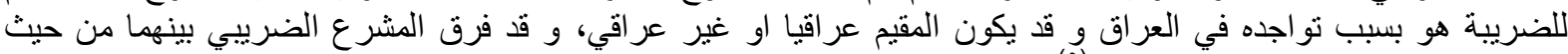

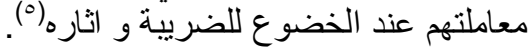

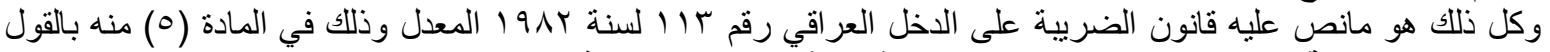

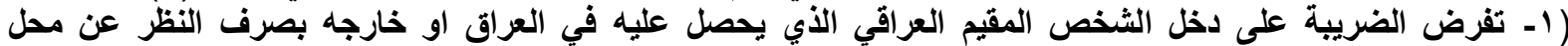

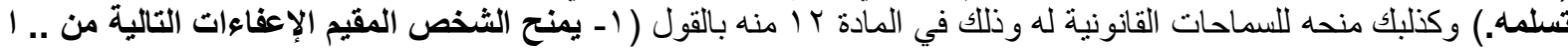

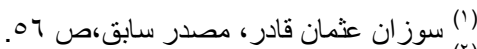

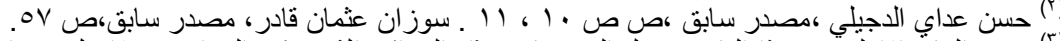

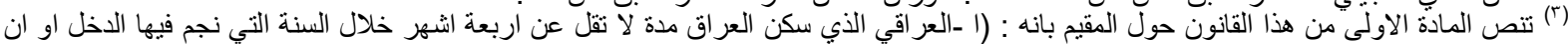

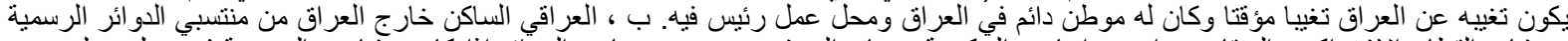

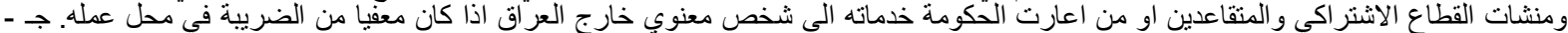

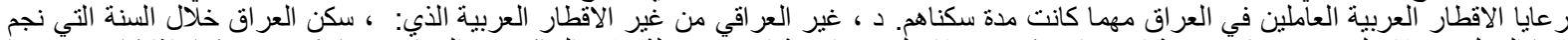

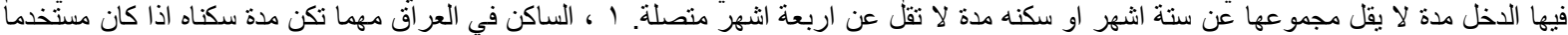

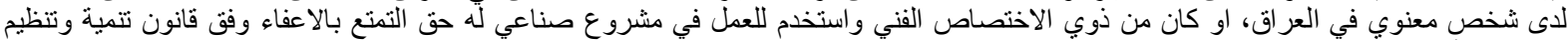

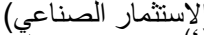

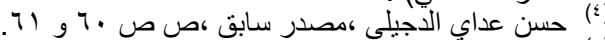

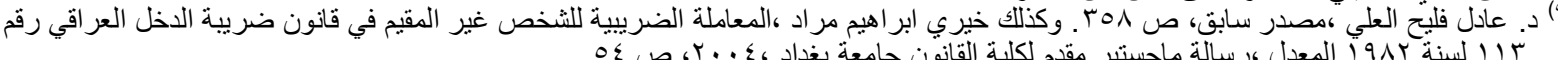


- مبلغ مليونين وخمسمائة ألف دينار عراقي د.ع لافع الضريبة شخصيا او لدافعة الضريبة اذا كانت غير متزوجة، عدا

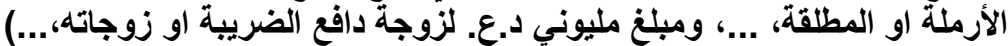

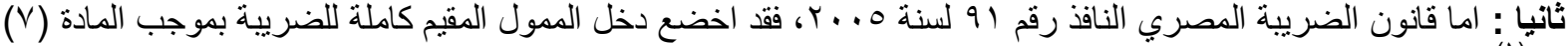

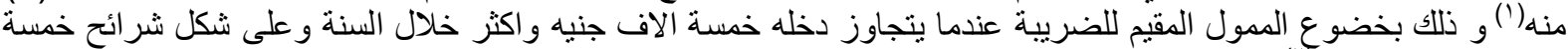

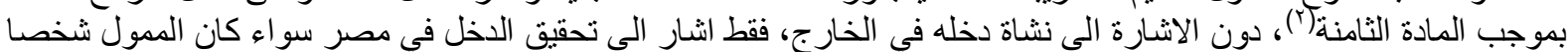

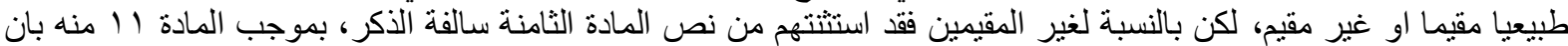

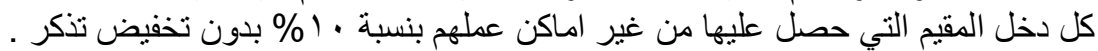

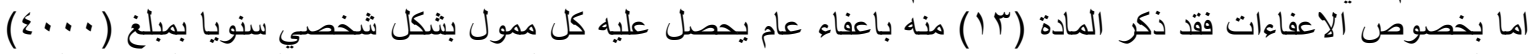

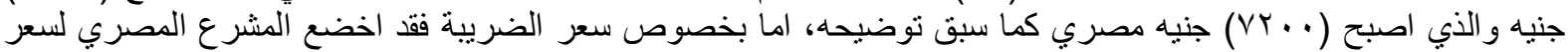

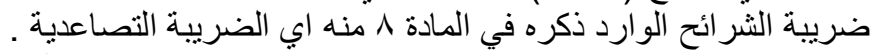
المطب الثني

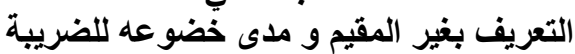

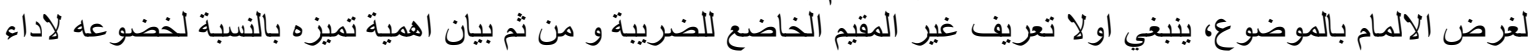

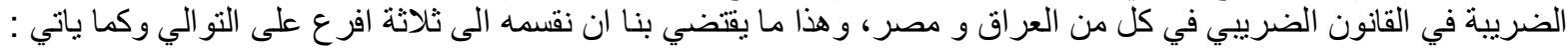

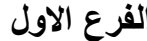

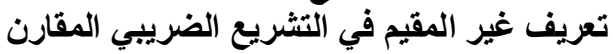

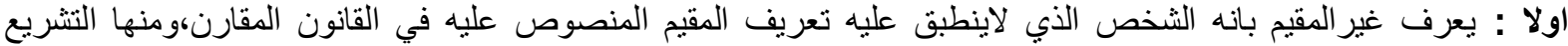

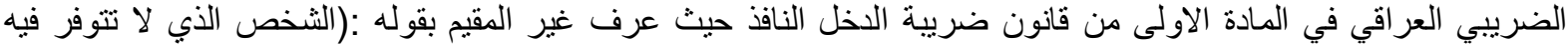

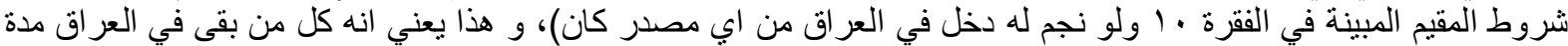

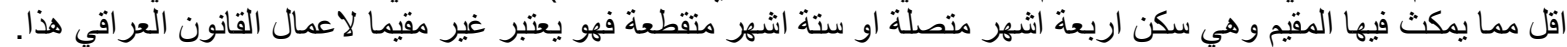

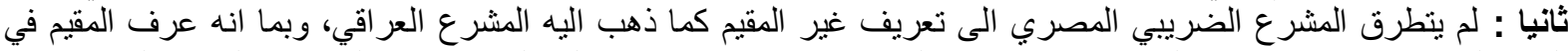

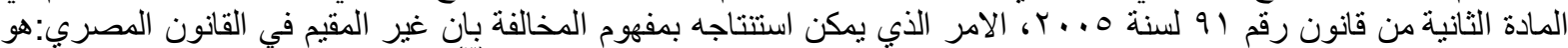

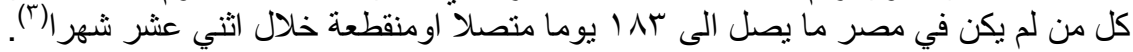
الفرع الثاني

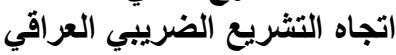

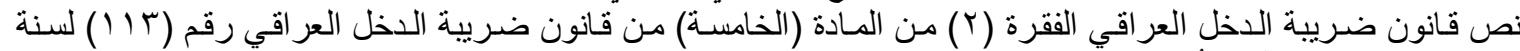

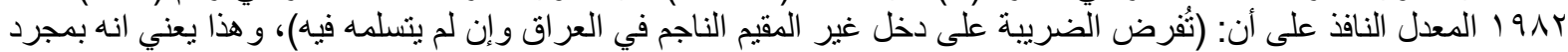

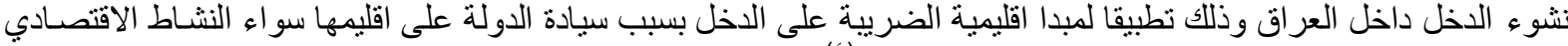

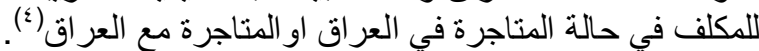

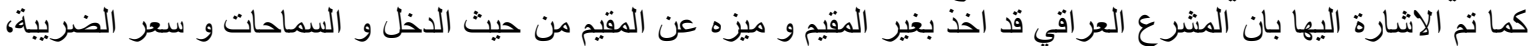

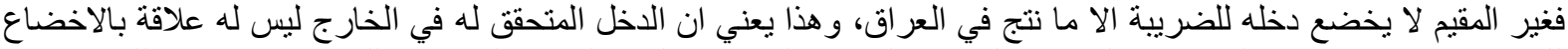

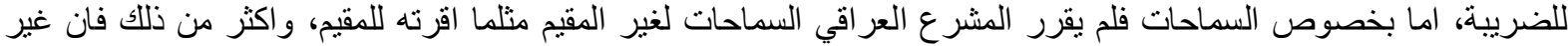

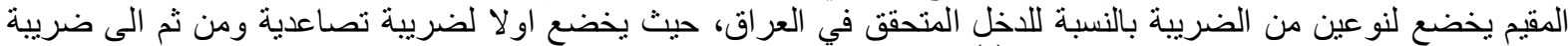
الفرع الثرالث الثري

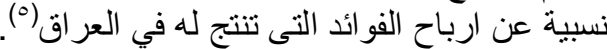

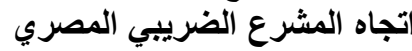

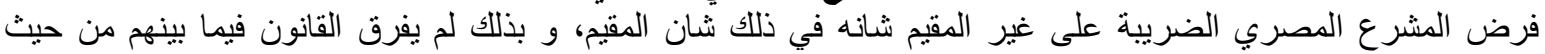

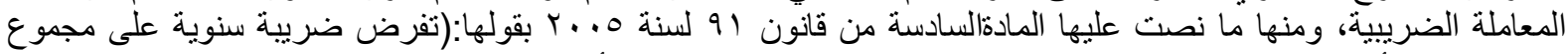

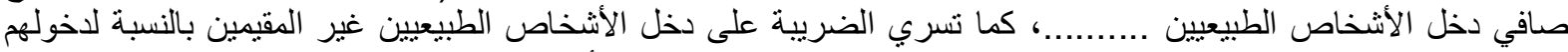

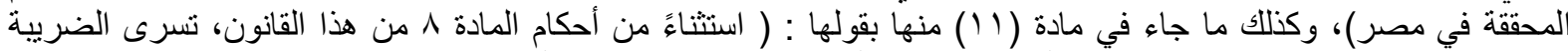

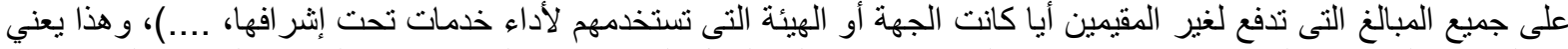

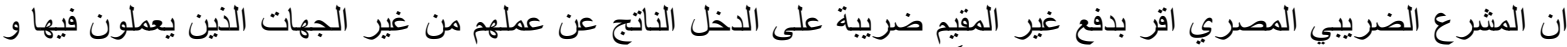

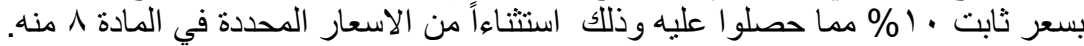

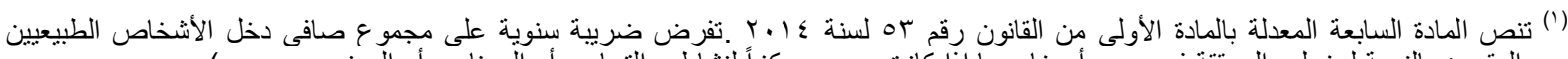

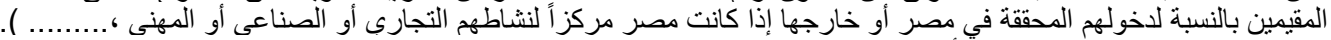

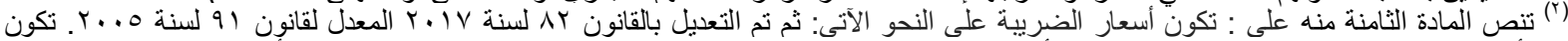

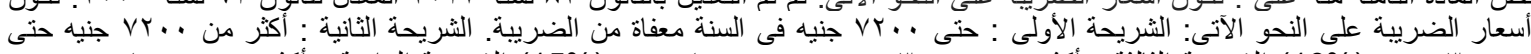

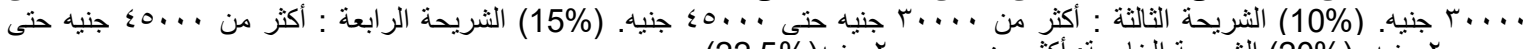

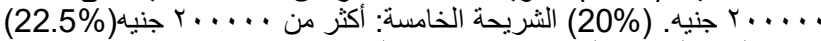

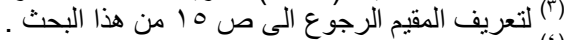

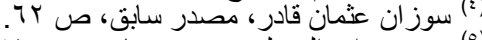

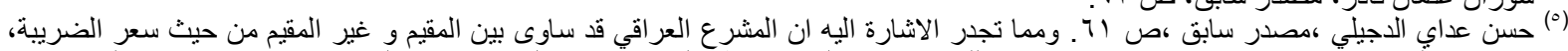

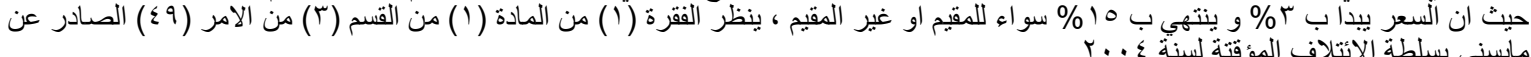


يستنتج مما تقدم في هذا المبحث بان المشرع العر اقي قد فرق فيما بين المقيم و غير المقيمن حيث خضوعهم للضيثر الضريبة و بشكل

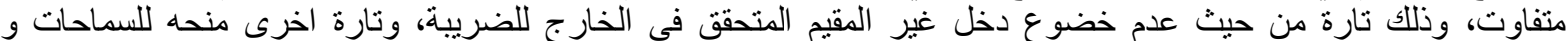

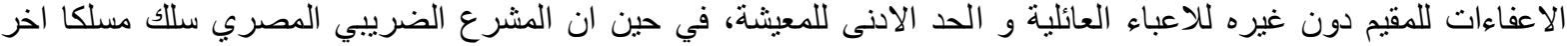

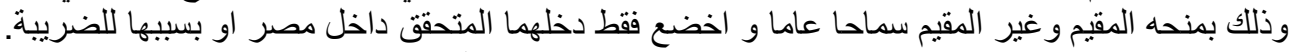

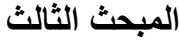

\section{التفريق الضريبي حسب دخل الاسرة}

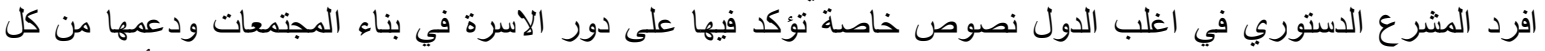

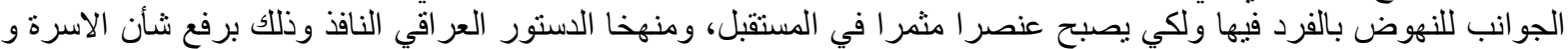

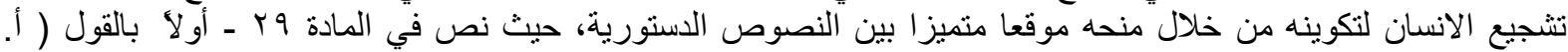

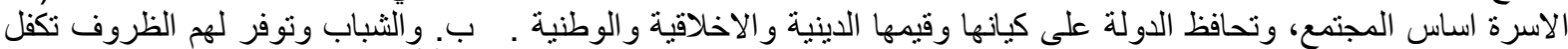

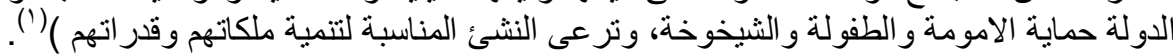

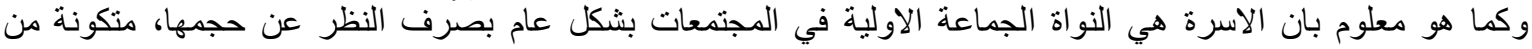

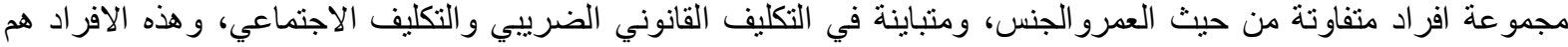

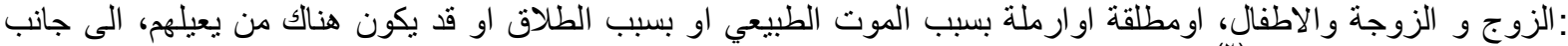

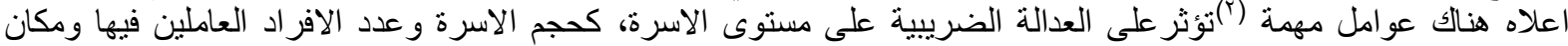

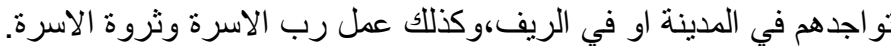

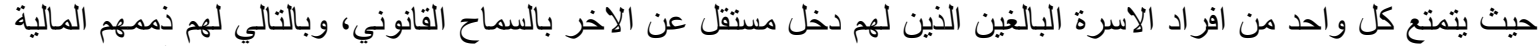

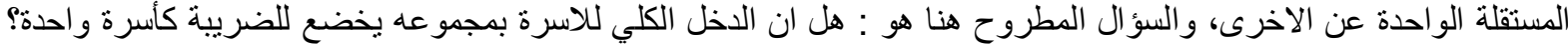

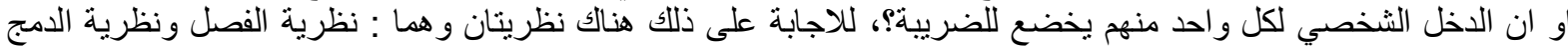

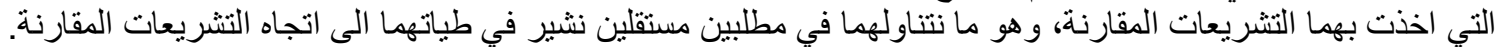

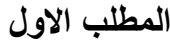

نظرية استقلال الأمم المالية في نطاق الأبرل الأبرة

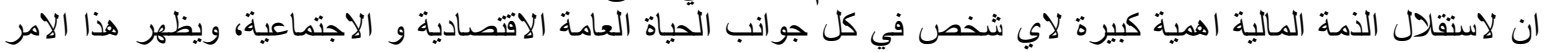

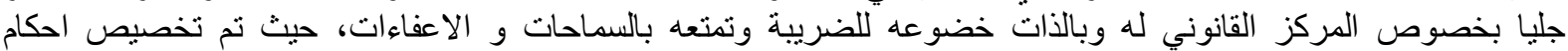

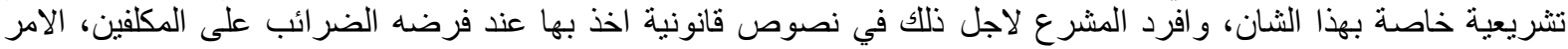

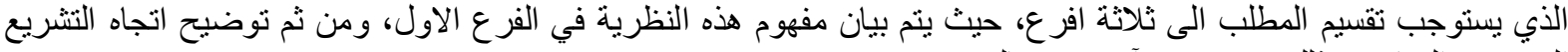

\section{الفرع الاول \\ تعريف نظرية استقلال الذمة المالية}

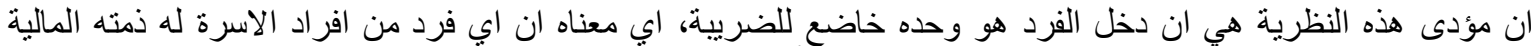

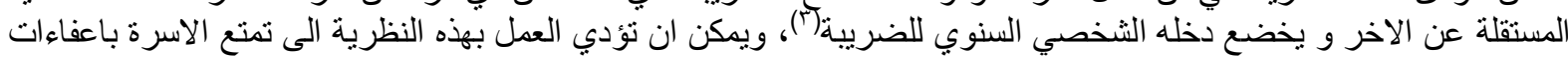

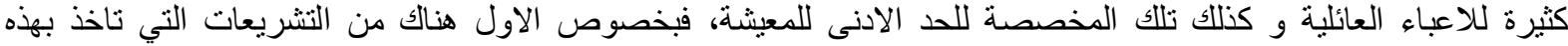

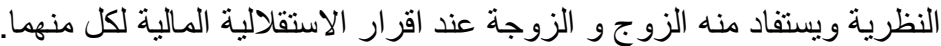

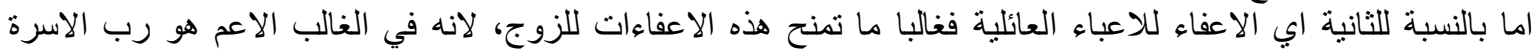

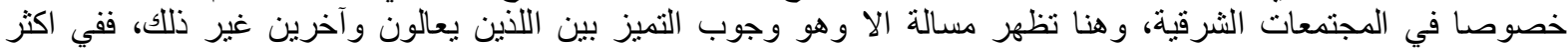

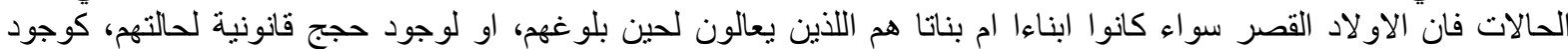

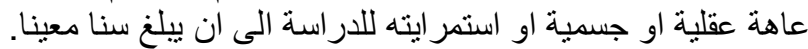

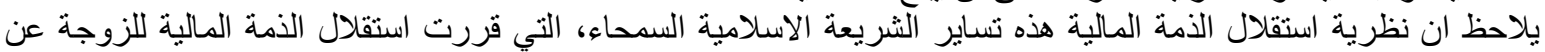

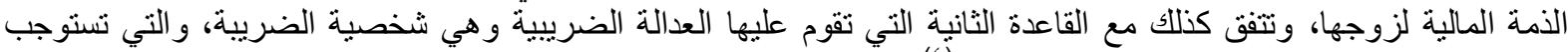

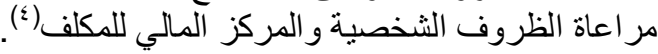

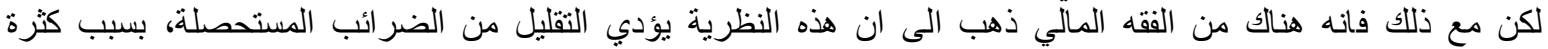

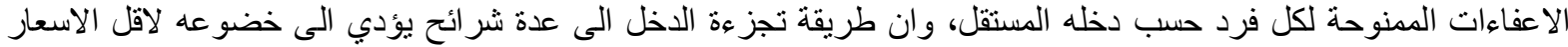

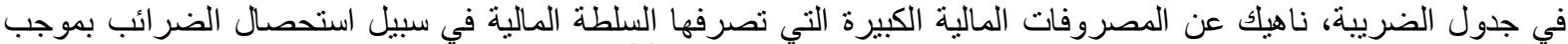

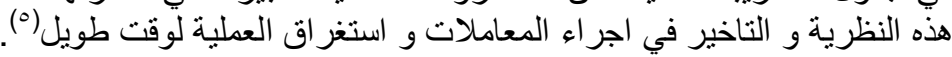

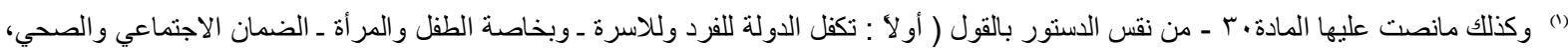

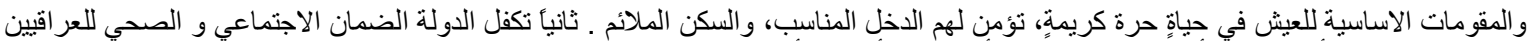

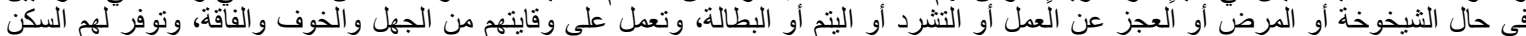

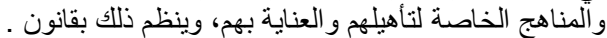

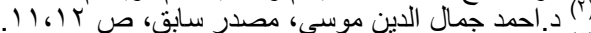

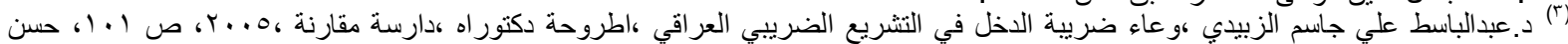

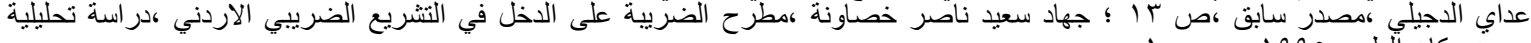

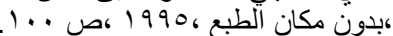

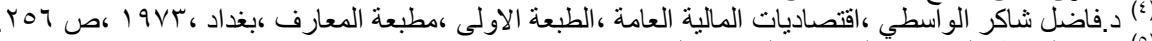

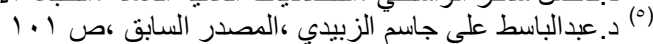




\section{اتجاه المشرع الضرعيبي العراقي}

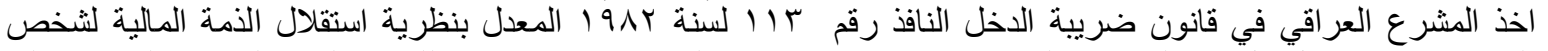

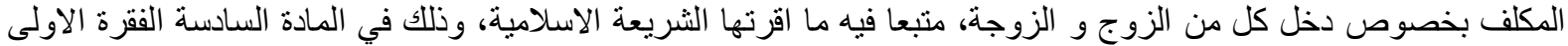

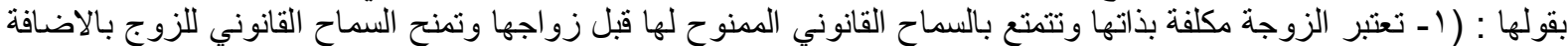

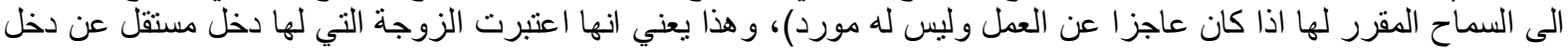

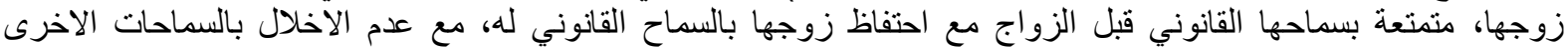

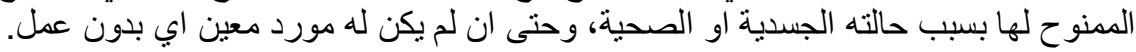

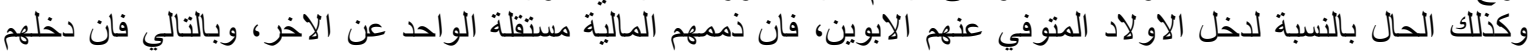

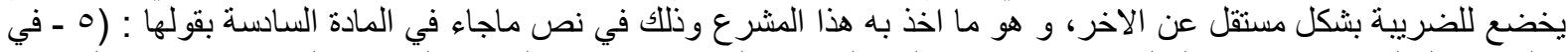

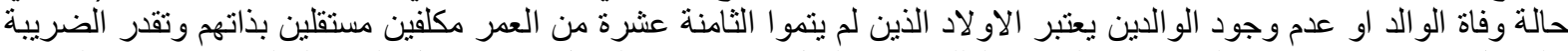

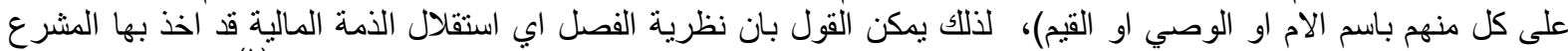

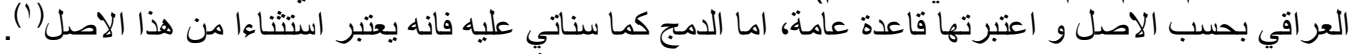

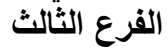

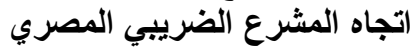

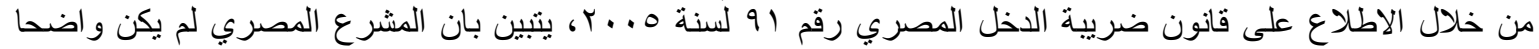

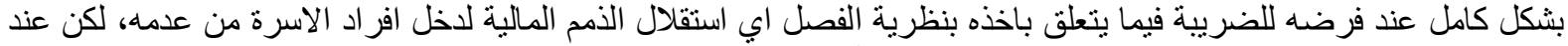

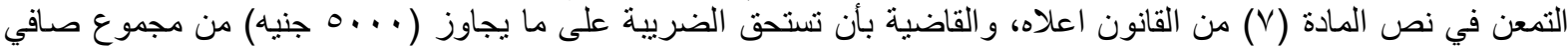

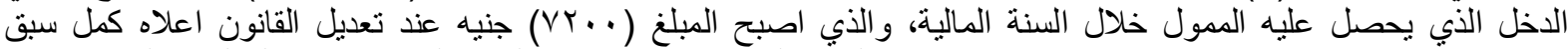

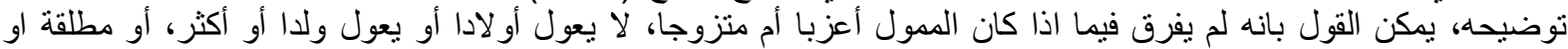

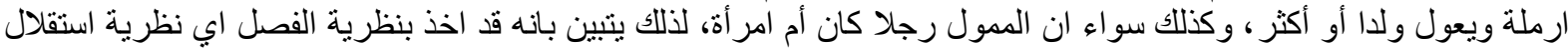

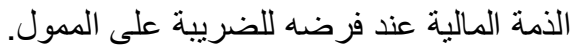

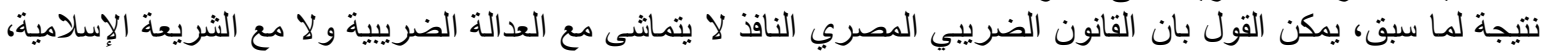

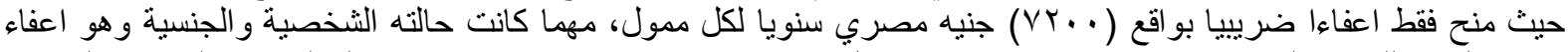

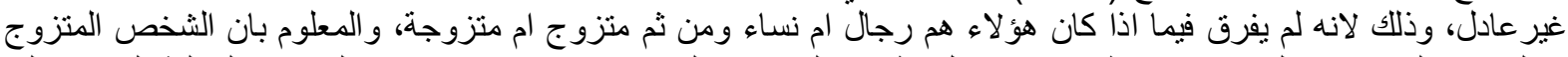

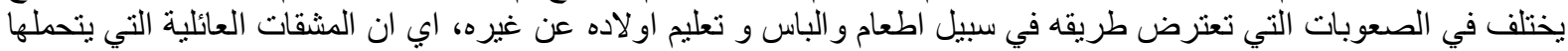

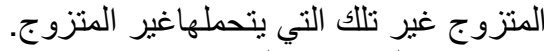

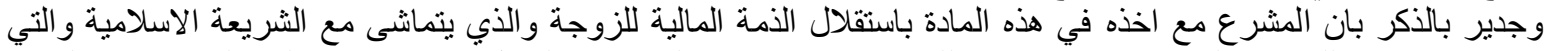

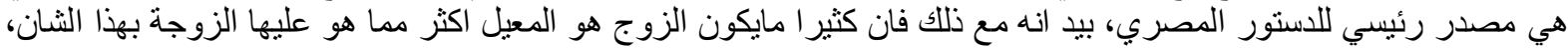

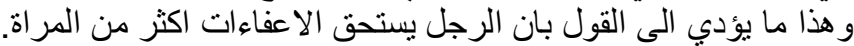

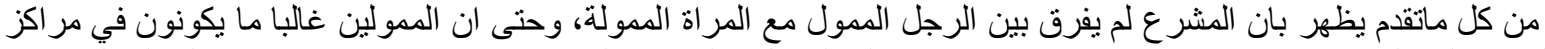

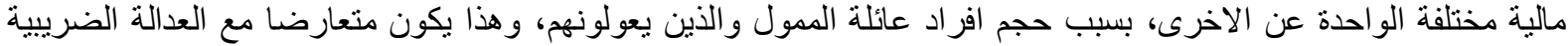

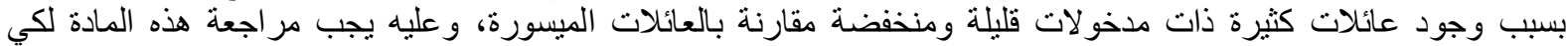

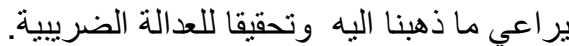

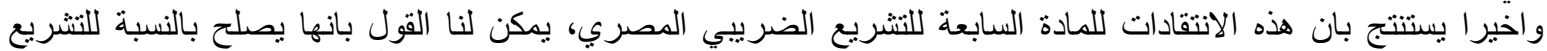

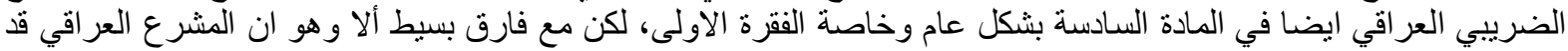

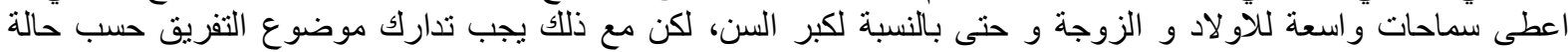

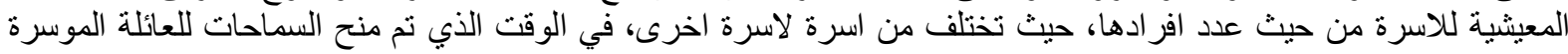

\section{المطلب الثاني \\ نظرية دمج ضريبة دخل الاسرة}

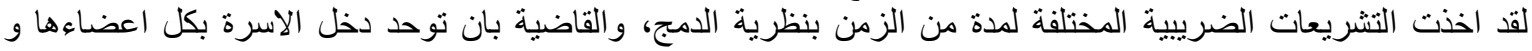

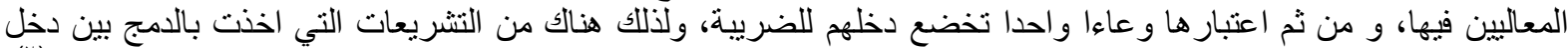

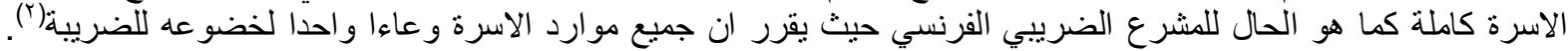

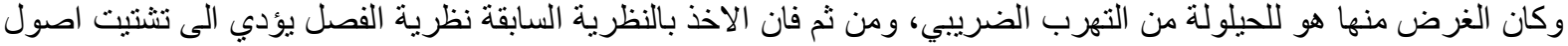

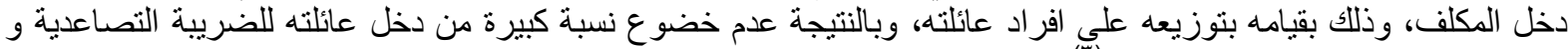

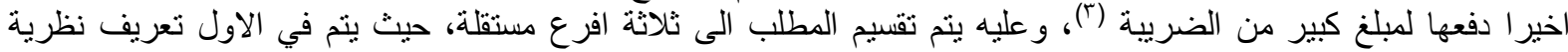
الدمج، اما في الاخريين فانه سيتم التطرق الى موقف التشريع المقارن حول النظرية.

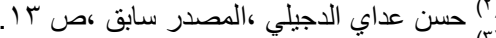

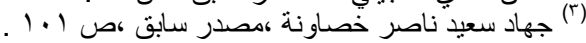




\section{الفرع الاول \\ تعريف نظرية الامج الضريبة الأول}

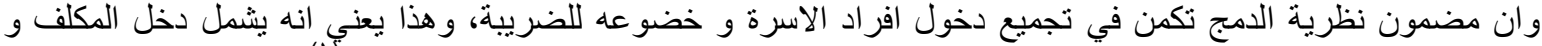

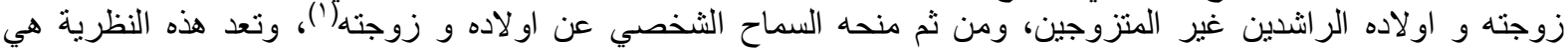

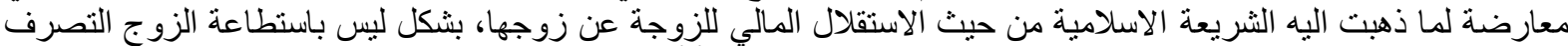

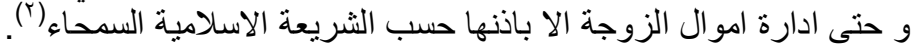

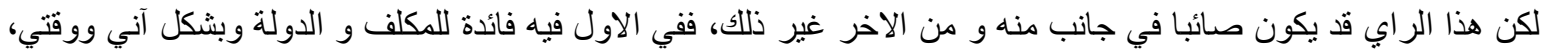

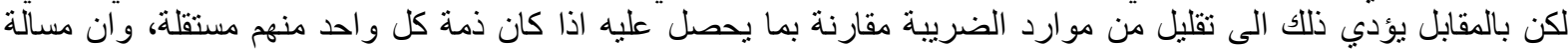

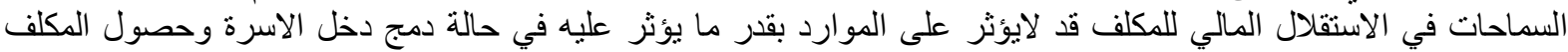
على كل هذه السماحات جملة واحدة.

\section{اتجاه المشرع الضرعيبي العراقي الثراني}

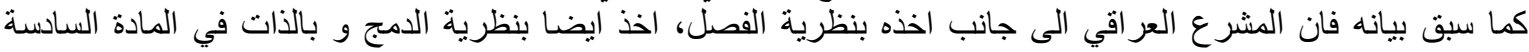

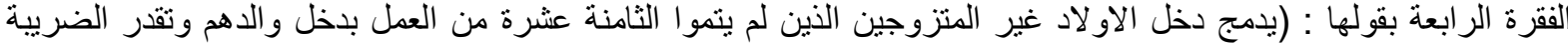

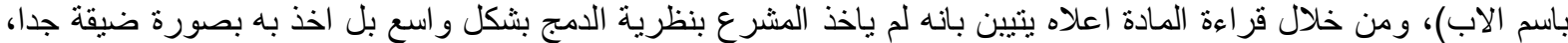

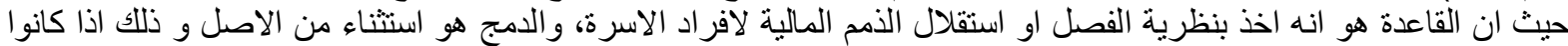

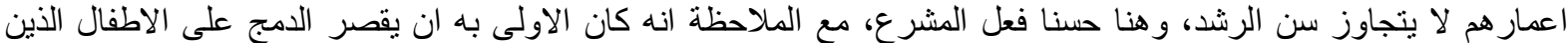

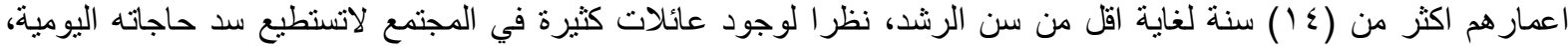

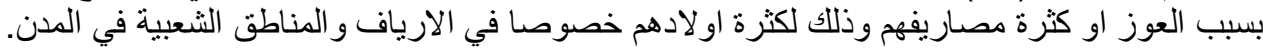

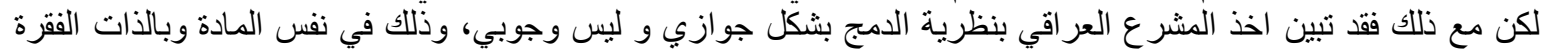

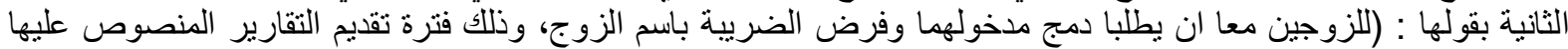

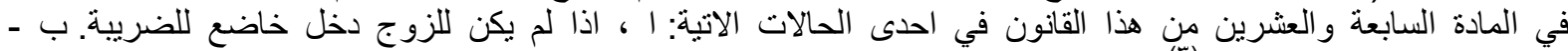
.

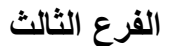

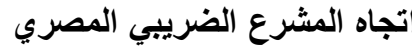

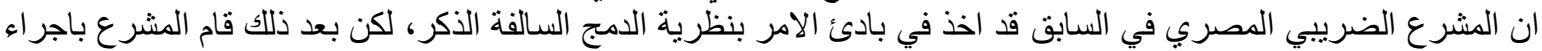

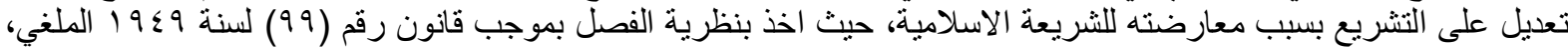

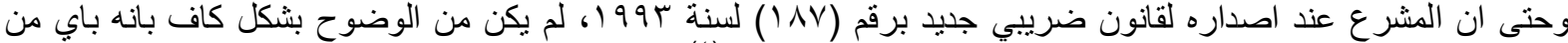

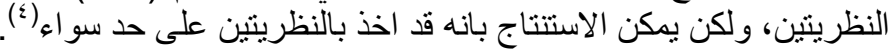

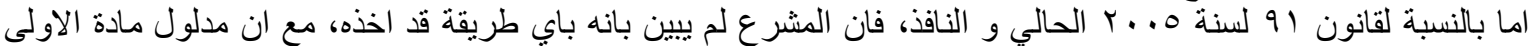

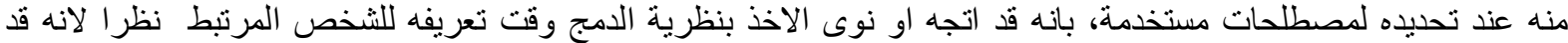

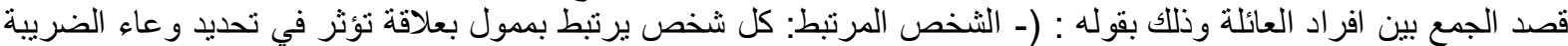

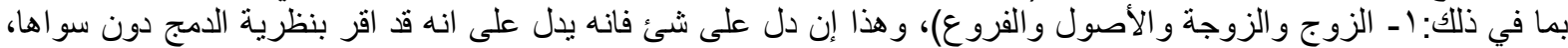

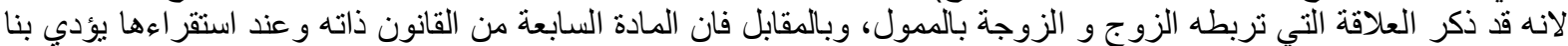

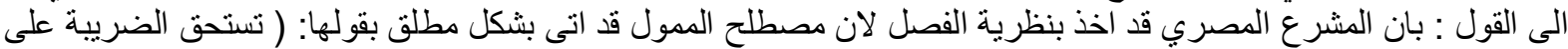

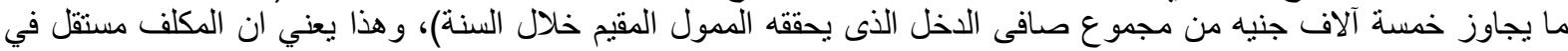

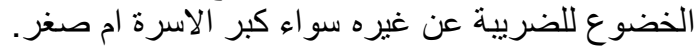

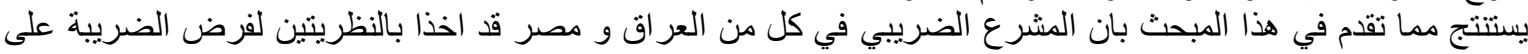

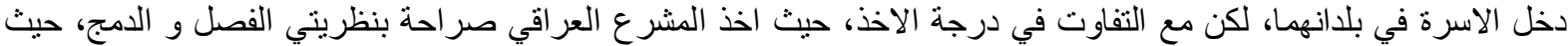

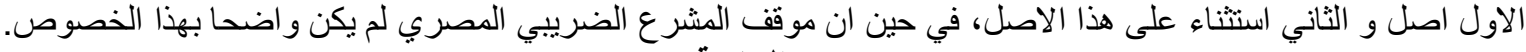
الخاتمة

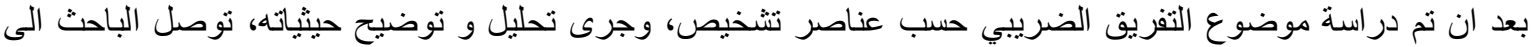

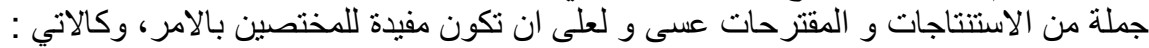

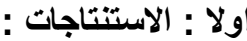

1- يتضح ان ماقام به المشرع الضريي العر اقي من تفريق من حيث الخضوع بعض الاشتخاص الطبيعين للضريبة

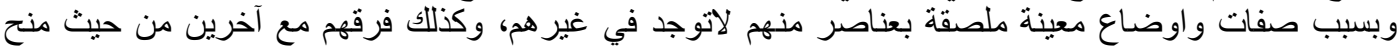

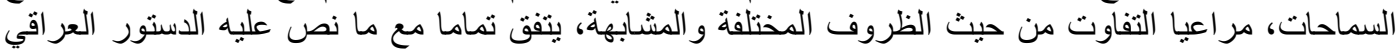

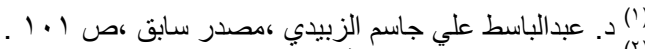

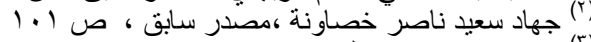

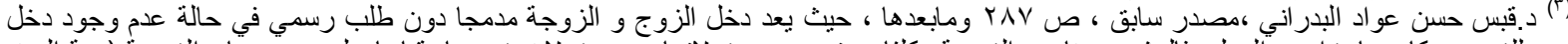

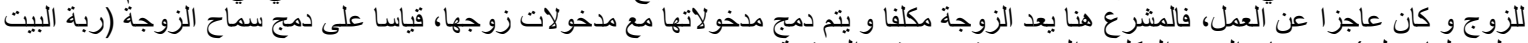

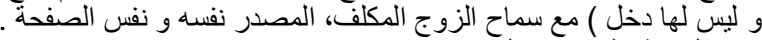

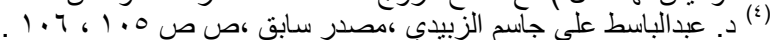




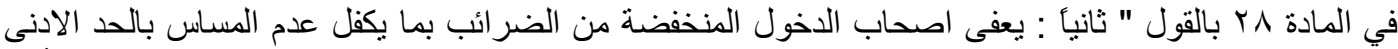

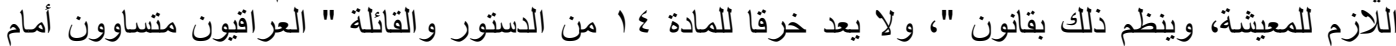

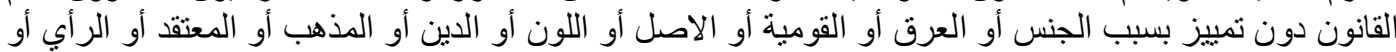

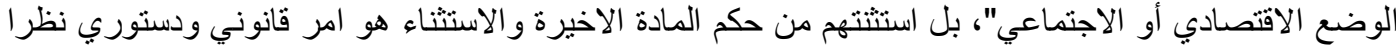

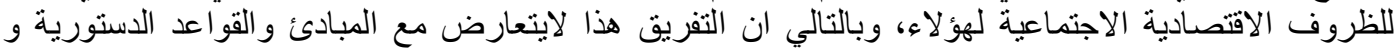

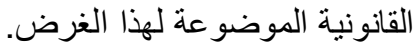

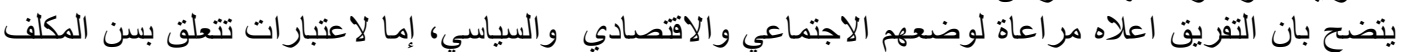

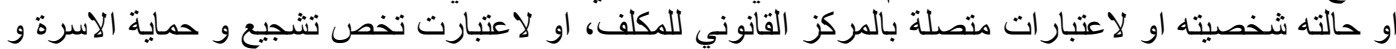

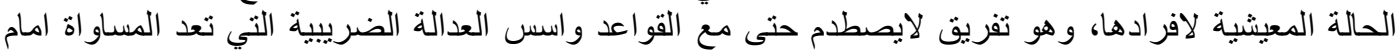

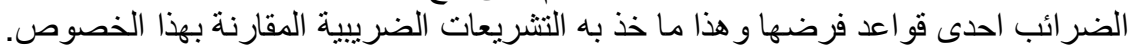

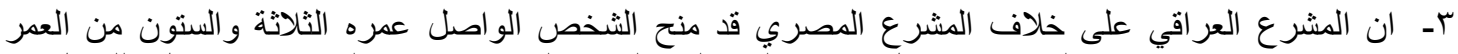

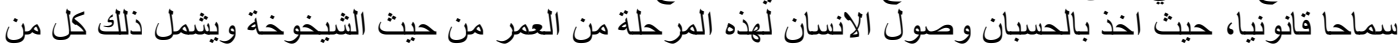

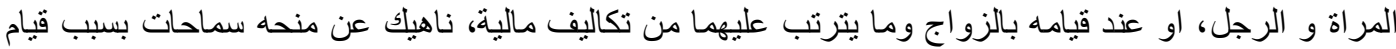

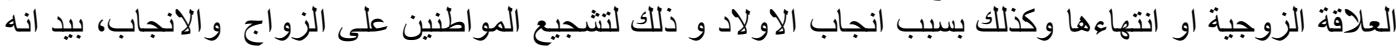

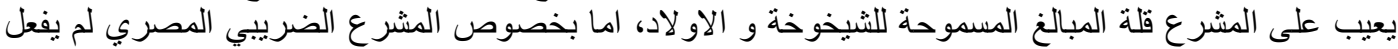

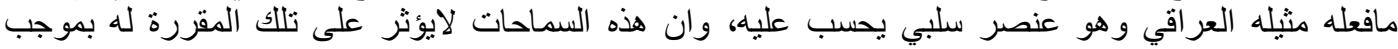
نصوص نفس القانون.

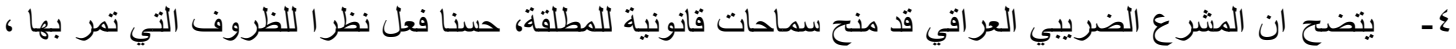

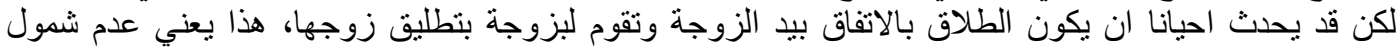

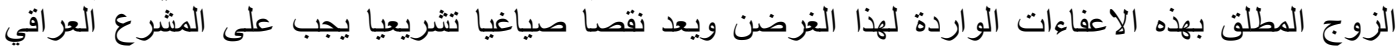

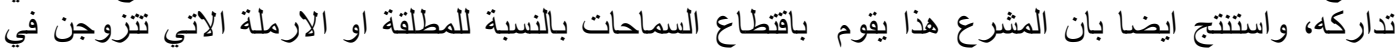

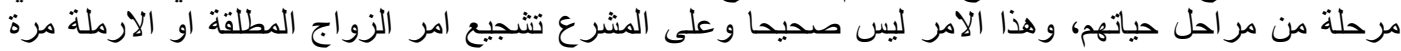

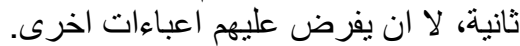

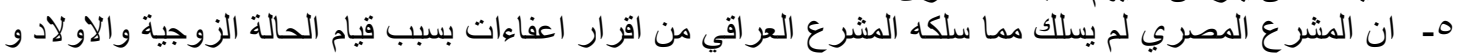

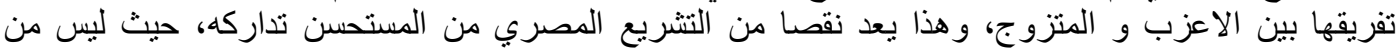

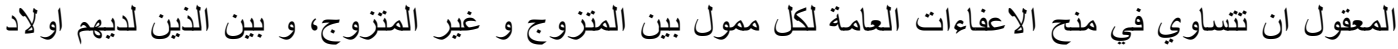

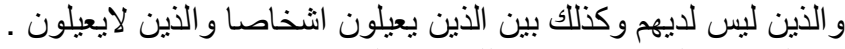

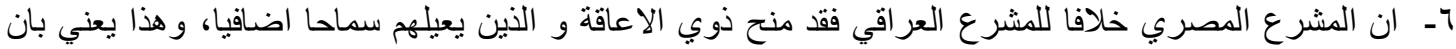

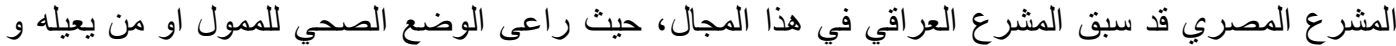

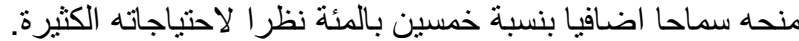

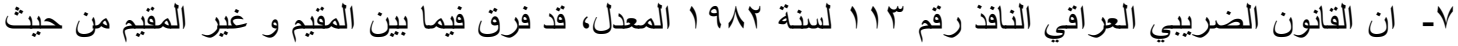

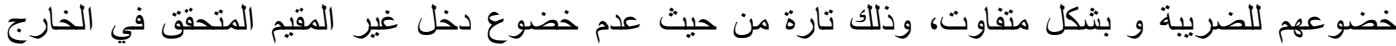

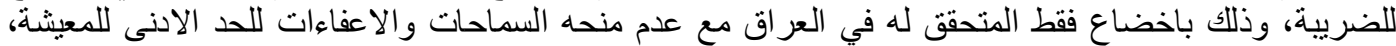

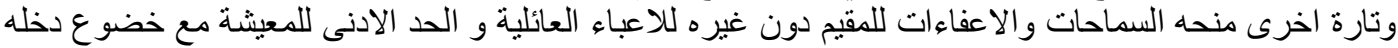

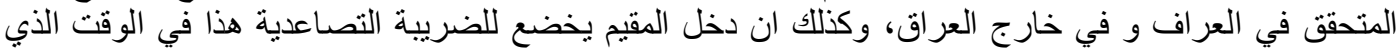

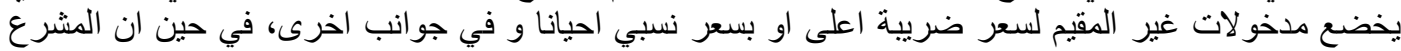

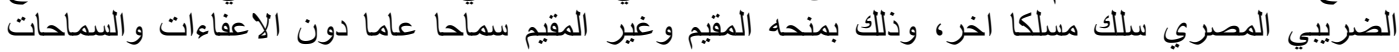

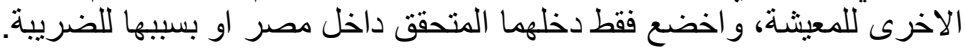

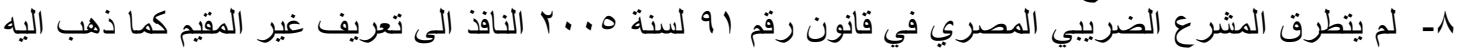

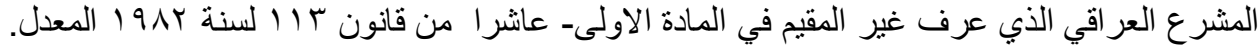

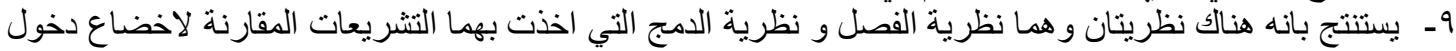

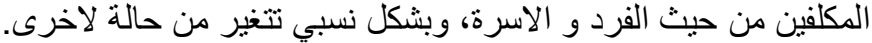

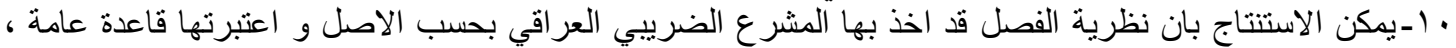

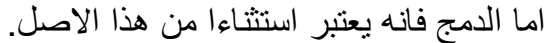

1)

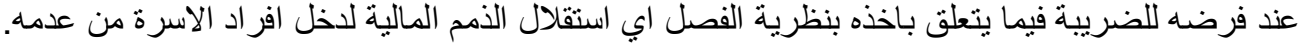

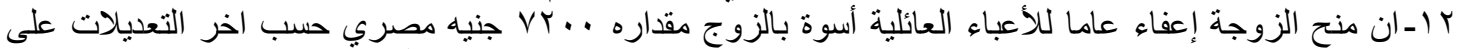

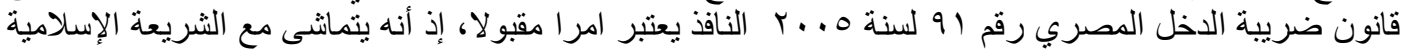

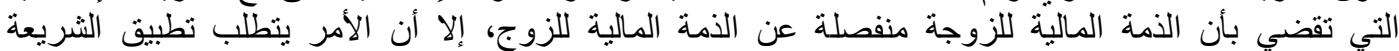

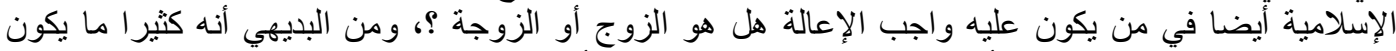

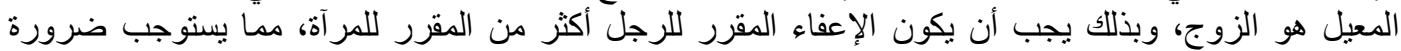

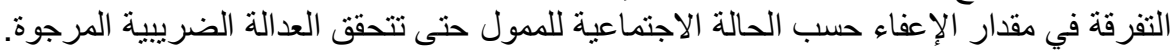




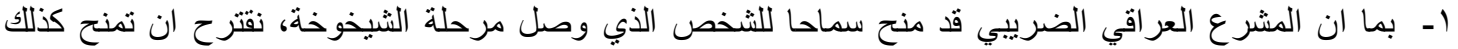

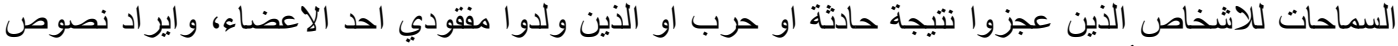
خاصة بمنح المعاقين أسوة بالمشر عائ عزئ المصري.

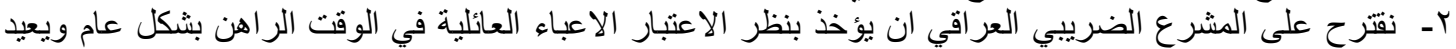

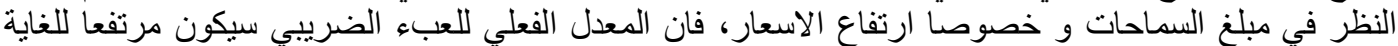

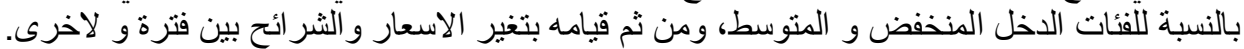

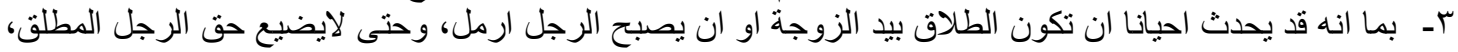

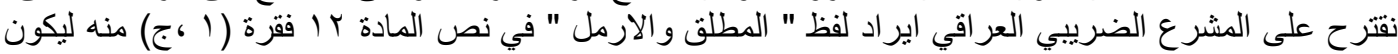

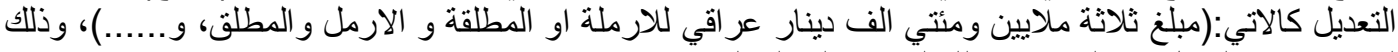

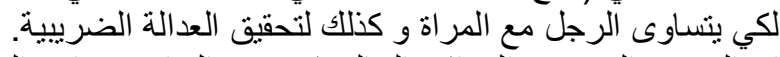

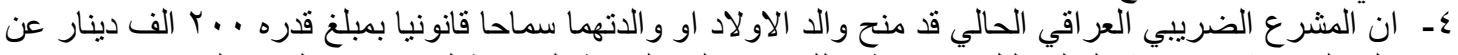

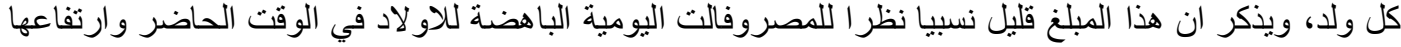

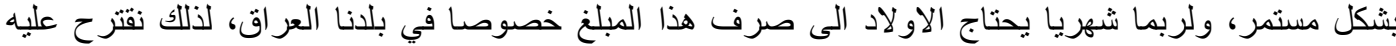

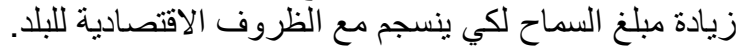

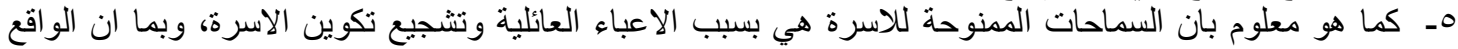

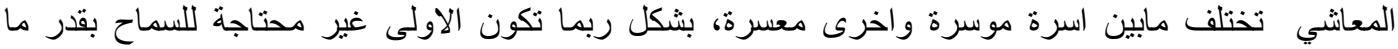
يحتاجه الثانية، لللك نقترح على المشرع الضريبي تدارك التفريق حسب الحالة المعيشية للاسرة، وذللك بمنحها

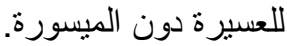

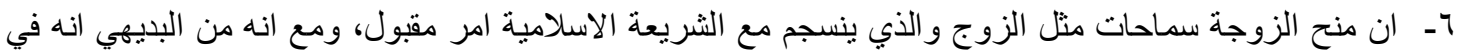

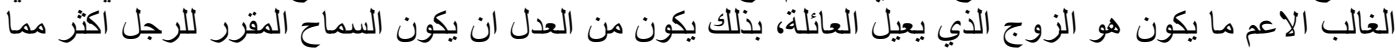

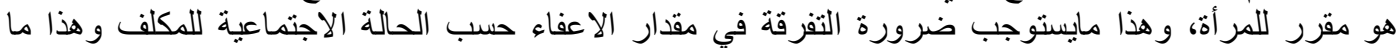

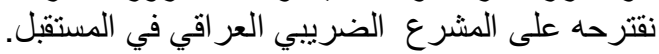

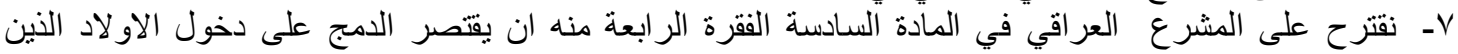

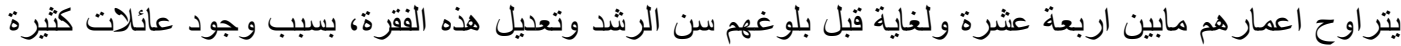

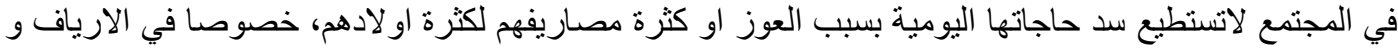

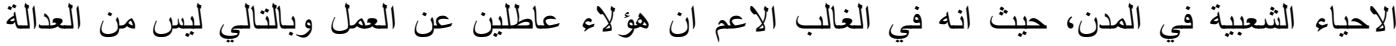

\section{ثبت المصادر والمراجع}

خضو عهم للضريبة.

ـ - د.احمد جمال الدين موسى ،"توزيع و اعادة توزيع الدخل القومي"، دبلوم القانون العام ،كلية الحقوق، جامعة المنصورة ،

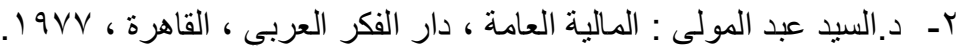

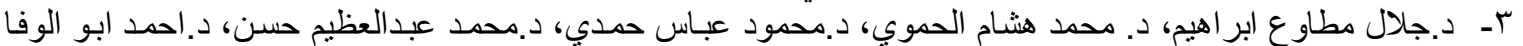

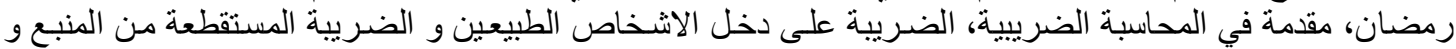

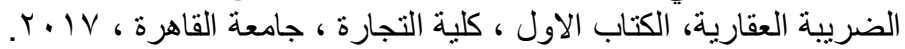

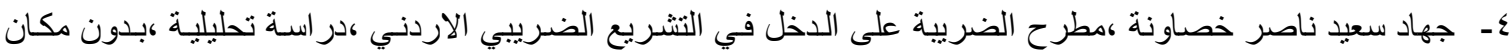

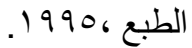

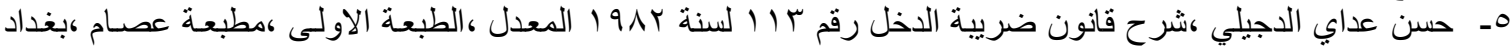
.1911 ،

T- ـ د.ر ائد ناجي احمد ،علم المالية العامة و التشريع المالي في العر اق ،الطبعة الاولى ،العاتك لصناعة الكتب ،القاهرة $r \cdot 1 r_{6}$

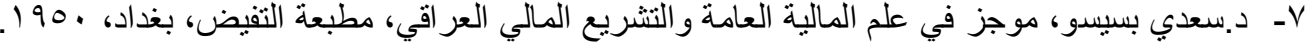

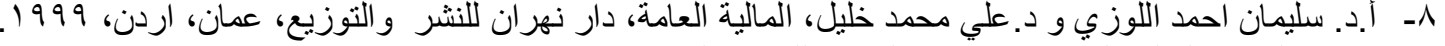

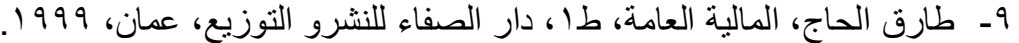

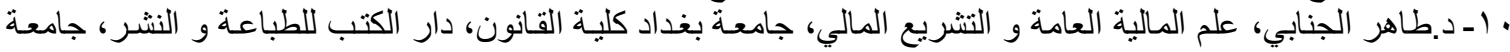

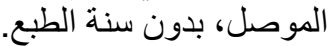

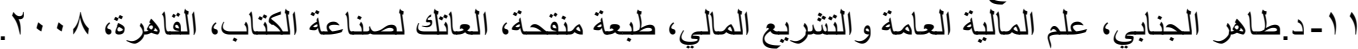

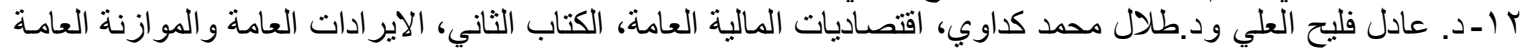

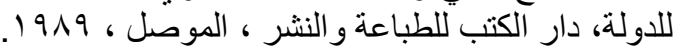

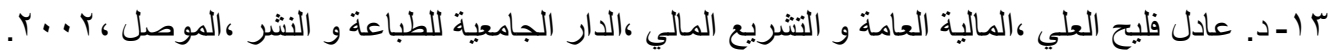

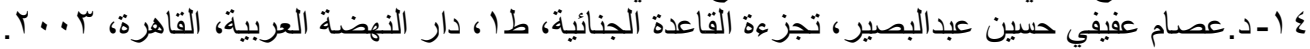


0

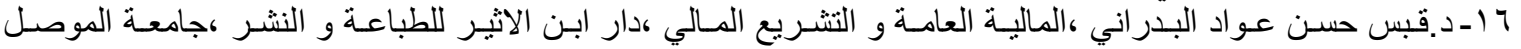

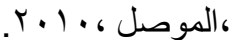

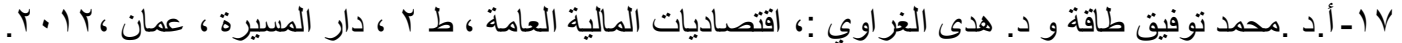

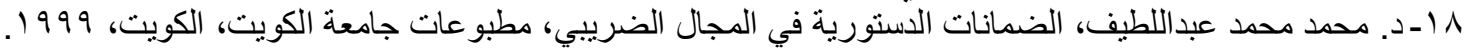

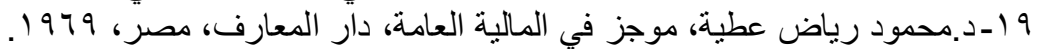

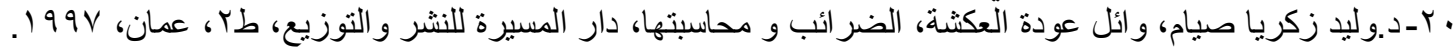

ثانيا :الرسائل والاطاريح

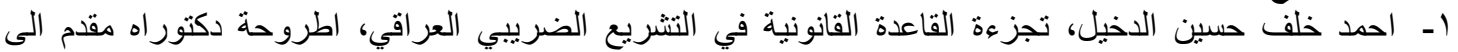

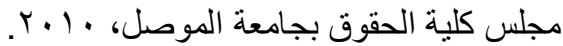

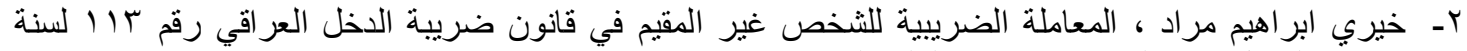

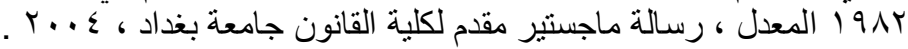

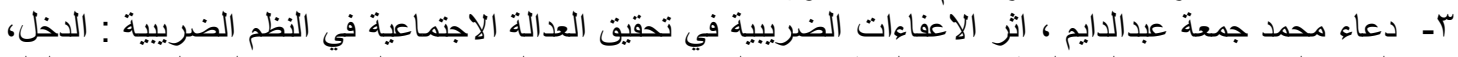
القيمة المضافة، الاملاك: المطبقة في فلسطين، رسالة ماجستير في المنازعات فات الضريبية فكلية الدراسات العاتيات العليا

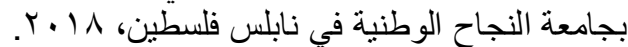

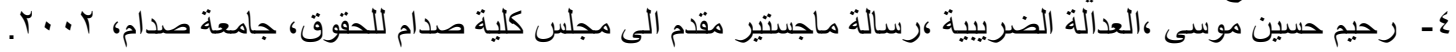

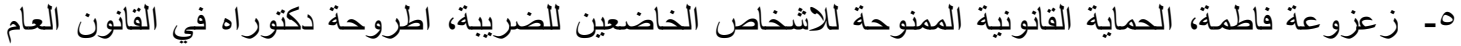

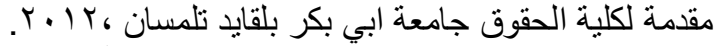

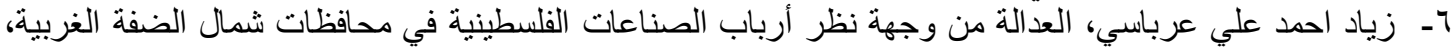
رسالة ماجستير في المنازعات الصريبية بكلية الدراسات العليا في جامعة النجاح الوطنية في نابلس، فلسطين، r...人

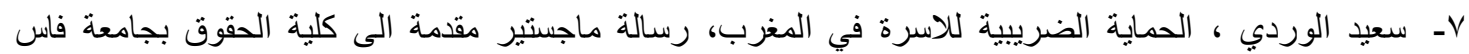

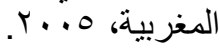

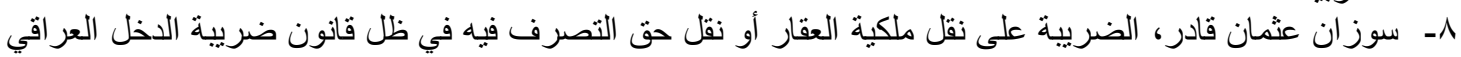

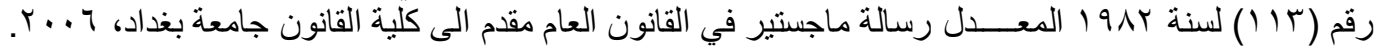

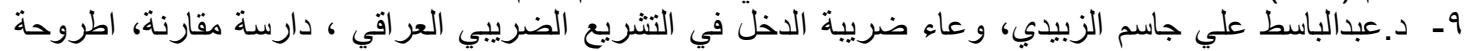

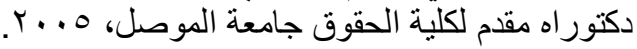

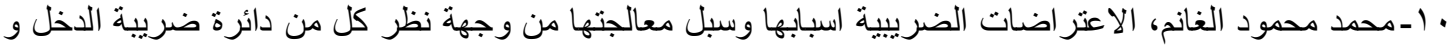

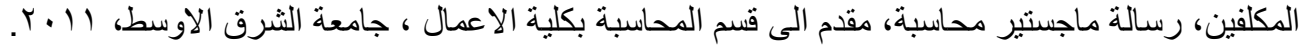

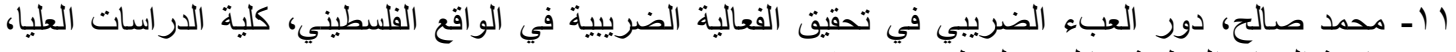

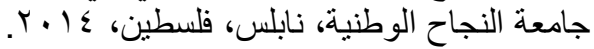

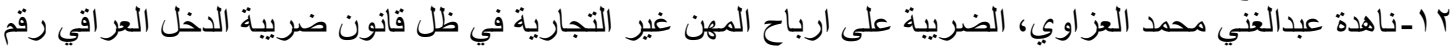

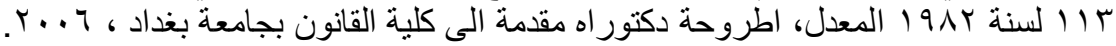
ثالثا : البحوث و المجلات : آنات

ا - أ.م.د.قبس حسن عو اد البدراني، لنجة صالح حمة طاهر، جامعة الموصل كلية الحقوق، الاعفاءات المقررة للنطاق

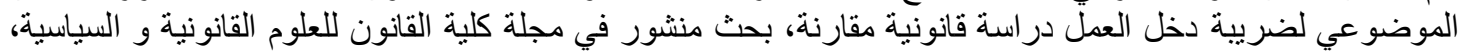
العراق، بدون عدد و سنة الطبع.

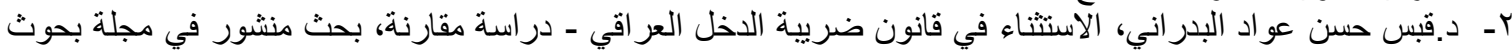

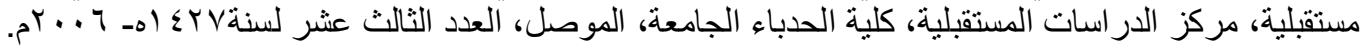

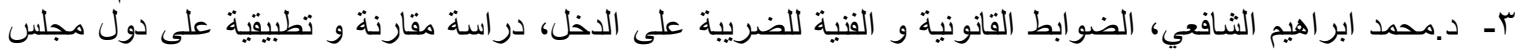

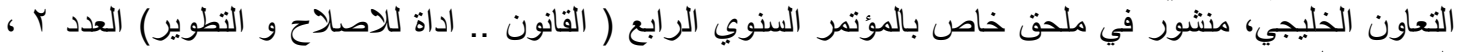

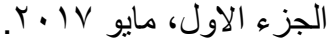
رابعا :القوانين :

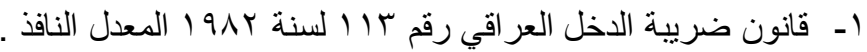

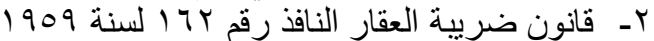

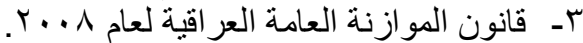

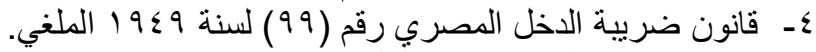

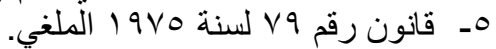

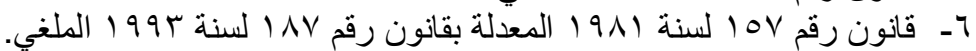

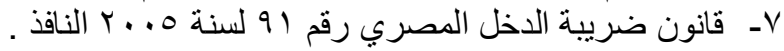

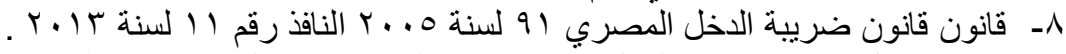

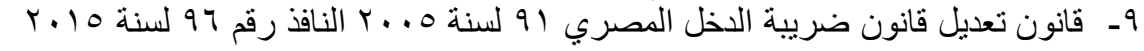




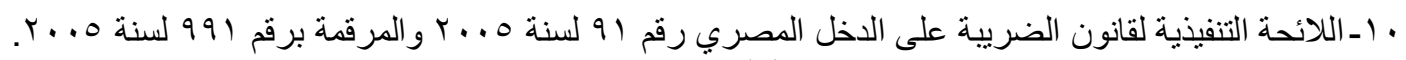

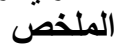

من بين المبادئ السامية التي ينبغي على البشر الالتز ام بها في حياته ويؤمن بها، هو مبدا التعايش و مراعاة الاخرين، لانها

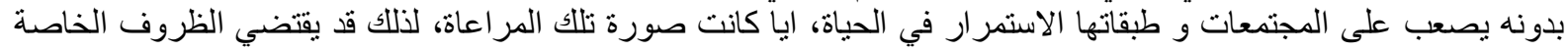

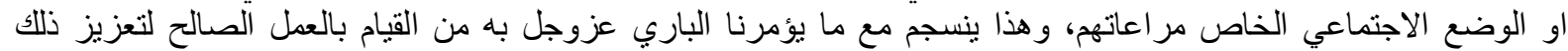

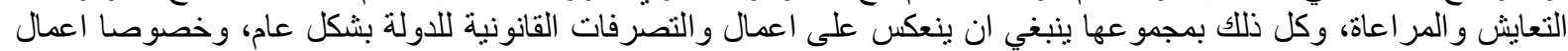

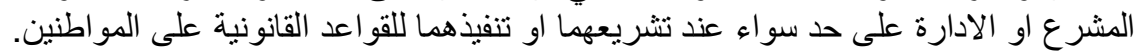

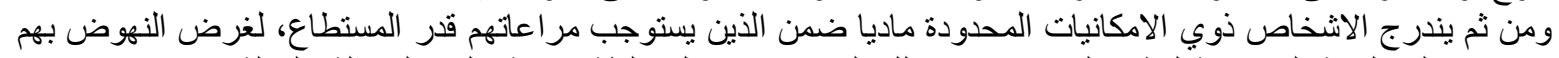

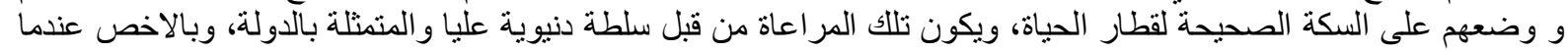

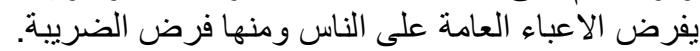

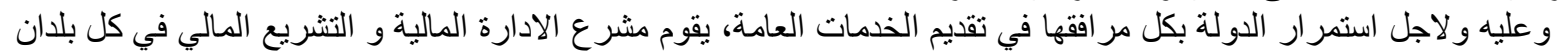

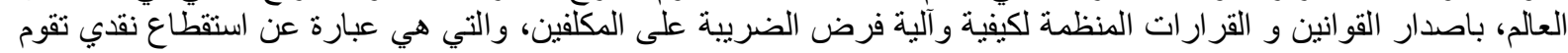

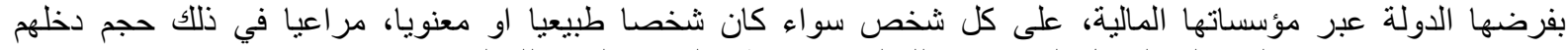

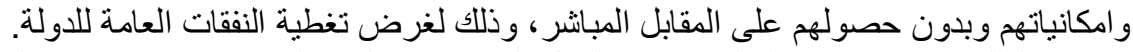

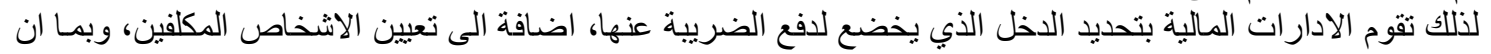

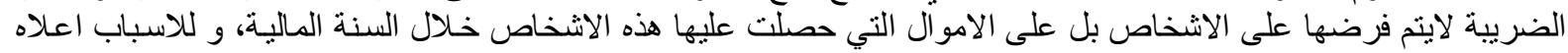

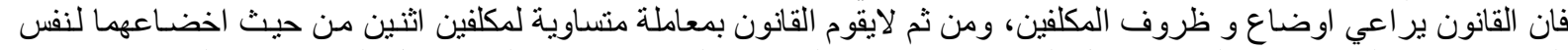

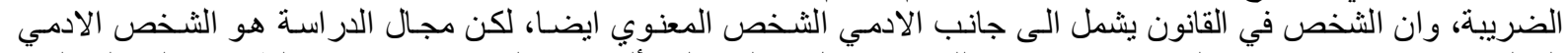

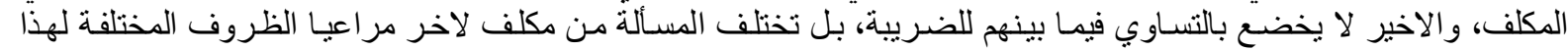

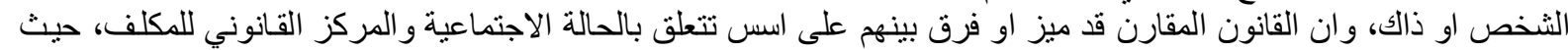

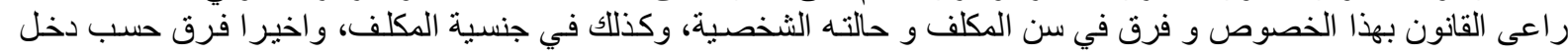

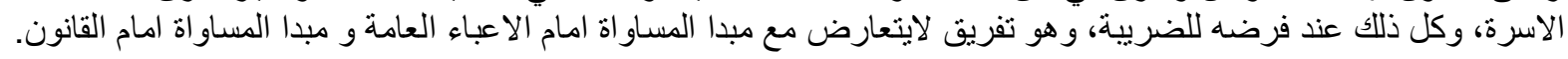




\begin{abstract}
:
Amongst the prominent principles that individuals must follow in their life and believe in it, is the principle of coexistence and taking others into account, because without these it would be difficult for the societies and their strata to survive, whatever was the form of this consideration, that is why special circumstances or special social situation may require their consideration. And this is consistent with what Allah Almighty commands us to do good deeds to enhance this coexistence and consideration, and all of that in a whole should reflect on the legal acts and behaviors of the country as a general, especially acts of a legislator or the administration separately whether when enacting or implementing the legal rules on the citizens.

And then the people with limited financial capabilities are enlisted along with those that should be taken into account as much as is achievable, for the purpose of advancing them and putting them on the right railway of life train. And this consideration is done by the state authority mainly when general burdens such as taxation are imposed on the public.

In addition to and for the state with all of its facilities to continue giving public services, a financial administration and legislation legislator in all the countries around the world issues regulatory laws and decisions for taxation modality and mechanism on the assigned people, which is basically deduction of cash that the state imposes by the way of its financial foundations, implied on each individual whether he/she was natural or legal by taking the size of his/her income and capabilities into consideration and without them getting the services immediately, in order to cover the state's general expenses.

That is why the financial departments determine the income that is to be deduced for taxation, as well as employing the assigned individuals. Since tax is not imposed on the people but the on the money that these people have gained during a fiscal year, and because of the reasons above, law does consider the conditions and circumstances of the assigned individuals, and indeed any individual in the law is considered to be a natural and a legal one, but the law does not treat the assigned individuals equally in doing the same taxation and the latter is not treated equally including the but rather the issue differs from a charged person to another depending on the different circumstances each one is in. And indeed comparative law has distinguished or differentiated between them on the basis of social status and legal position of the assigned person, where the law has taken these, age differences, personal status, nationality, and differentiation according family income into account when imposing taxes, and it is a differentiation method that does not oppose the equality principle before the general burdens' and the law.
\end{abstract}

Keywords: tax, financial legislation, financial administration. 